SOUTH EAST EUROPE

Transnational Cooperation Programme
SNAPDS SEE

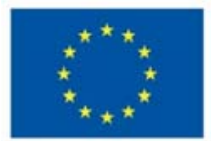

Programme co-funded by the EUROPEAN UNION

Të dhëna dhe Metodologjia Analitike për Planifikimin e Agregateve: Në mbështetje të praktikave më të mira për Planifikimin e Qëndrueshëm të Agregateve

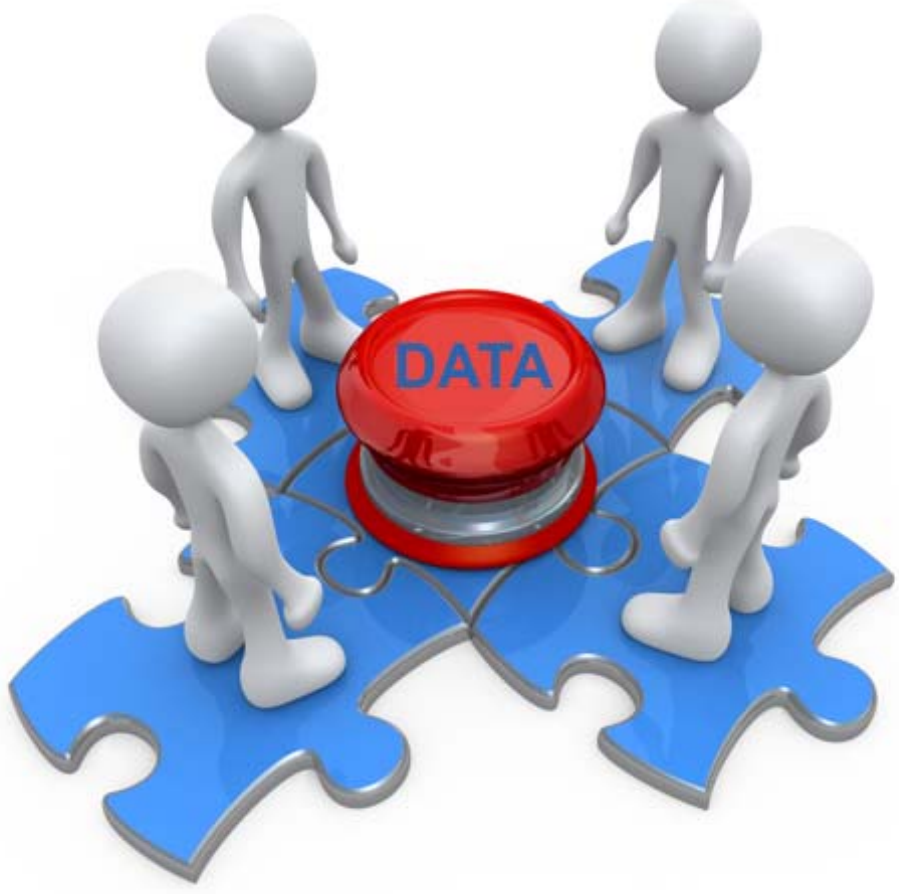

Maj 2014
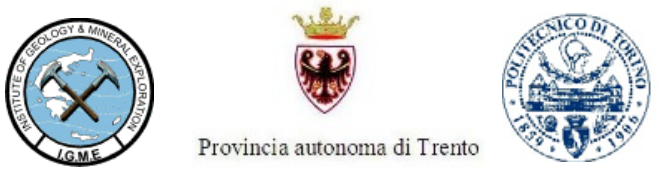



\section{Të dhëna dhe Metodologjia Analitike për Planifikimin e Agregateve: \\ Në mbështetje të praktikave më të mira për Planifikimin e Qëndrueshëm të Agregateve}

\section{Bazuar në:}

Raportin e përgatitur në kuadër të Paketës së Punës 4 të MQBA-EJL Projekt "Planifikimi i Qëndrueshëm i Agregateve në Europën Jug Lindore" (SEE/D/0167/2.4/X)

\section{website:http:// www.snapsee.eu}

Produkti i Aktivitetit: Manual mbi të Dhënat dhe Metodologjinë Analitike për Planifikimin e Agregateve: Një manual i përbashkët për autoritetet planifikuese në rajonin e Europës Jug Lindore.

\section{Digital Object Identifier (DOI)} doi:10.5474/snapsee-WP4-SQ

\section{Informacion mbi botimin}

$\begin{array}{ll}\text { Redaktimi: } & \text { Foteini Stathogianni } \\ \text { Dizenjimi i Kopertinës: } & \text { Stelios Mavrigiannakis } \\ \text { Botimi: } & \text { Geological Survey of Slovenia } \\ \text { Viti i Botimit: } & 2014\end{array}$

\section{Përgjegjësia mbi botimin}




\begin{tabular}{|c|c|}
\hline & $\begin{array}{l}\text { Agioutantis, Zach,Dr.,Universiteti Teknik i Kretës (TUC), Greqi } \\
\text { Komnitsas, Kostas, Dr., Universiteti Teknik i Kretës (TUC), Greqi } \\
\text { Steiakakis, Manolis, Dr., Universiteti Teknik i Kretës (TUC), Greqi } \\
\text { Mavrigiannakis, Stelios, Universiteti Teknik i Kretës (TUC), Greqi } \\
\text { Stathogianni, Foteini, Universiteti Teknik i Kretës (TUC), Greqi }\end{array}$ \\
\hline & $\begin{array}{l}\text { Chalkiopoulou, Fotini, Instituti i Gjeologjisë dhe Shfrytëzimit të } \\
\text { Mineraleve, Greqi } \\
\text { Hatzilazaridou, Kiki, Instituti i Gjeologjisë dhe Shfrytëzimit të Mineraleve, } \\
\text { Greqi }\end{array}$ \\
\hline Provincia autonoma di Trento & $\begin{array}{l}\text { Moltrer, Alessandro, Provinca autonome Trento- Agjencia Lokale e } \\
\text { Mbrojtjes së Mjedisit, Itali } \\
\text { Valbusa, Michele, Provinca autonome Trento- Agjencia Lokale e } \\
\text { Mbrojtjes së Mjedisit, Itali }\end{array}$ \\
\hline & $\begin{array}{l}\text { Bobba, Silvia, Politekniku i Torinos, Itali } \\
\text { Blengini, Gian Andrea, Dr., Politekniku i Torinos, Itali }\end{array}$ \\
\hline
\end{tabular}

\section{Recensent}

Emri Përktësia

Shields, Deborah J., Dr. $\quad$ Universiteti Shtetëror i Kolorados, Shtetet e Bashkuara të Amerikës

O’Brien, Jim

Ish President i Shoqatës Europiane të Agregateve, Iralandë

Simic, Vladimir, Dr.

Universiteti i Beogradit, Fakulteti Gjeologji Miniera, Serbi

\section{Mirënjohje}

Partnerët e projektit MQBA-EJL falenderojnë Komisionin Europian për financimin e këtij projekti, I cili lejoi zhvillimin e këtij manuali dhe solli një bashkëpunim të frytshëm ndërmjet partnerëve të cilat ndajne pikpamje të përbashkëta.

Autorët njohin kontributin e të gjithë partnerëve në zhvillimin e materialit të prezantuar në këtë manual.

\section{Referencë}

Ky manual mund të citohet në bibliografi si vijon: Agioutantis Z. et al. (2014), Manual mbi të Dhënat dhe Metodologjinë Analitike për Planifikimin e Agregateve: Një manual i përbashkët për autoritetet planifikuese në rajonin e Europës Jug Lindore, MQBA-EJL, 2014 
Të dhëna dhe Metodologjia Analitike për Planifikimin e Agregateve: Në mbështetje të praktikave më të mira për Planifikimin e Qëndrueshëm të Agregateve

PËRMBAJTJA

Faqja

\section{Parathënie}

5

1 Informacion prezantues

1.1 Nevoja për Planifikimin e Agregateve 8

1.2 Qëllimi dhe Struktura e Manualit 9

1.3 Përkufizimet e Termave të Përzgjedhur 9

$1.4 \quad$ Kategorite e Agregateve 15

2 Rëndësia e të Dhënave dhe Metodave të Analizimit për Planifikim 17

2.1 Vlerësime të Përgjithshme 18

2.2 Rëndësia e të Dhënave për Planifikim të Qëndrueshëm 19

2.3 Disponueshmëria e të Dhënave në vendet e Europës Juglindore 21

3 Organizimi i Inforamacionit 25

3.1 Komponentët e Planifikimit $\quad 26$

3.2 Krijimi i Matricës së Informacionit $\quad 27$

3.3 Kufizime 30

$4 \quad$ Identifikimi i Nevojave për të Dhëna 31

4.1 Prezantim 32

$4.2 \quad$ Formati i të dhënave 32

4.3 Identifikimi i grupit kryesor të të dhënave për Agregatet Parësor 33

4.4 Identifikimi i grupit kryesor të të dhënave për Agrefatet Dytësor 39

4.5 Shembuj të formateve të të dhënave për mbledhjen e tyre 42

$5 \quad$ Metodat e Analizës $\quad 45$

5.1 Prezantim 46

5.2 Vleftësimi i të dhënave 46

$5.3 \quad$ Analiza e rrjedhës së materialit 49

5.4 Parashikimi i kërkesës 49

$6 \quad$ Rekomandime $\quad 55$

6.1 Rekomandime të Përgjithshme 56

6.2 Rekomandime për të Dhënat dhe Metodologjinë e Analizimit te të $\mathbf{5 7}$

$7 \quad$ Referencat $\quad 59$ 


\section{Parathënie}

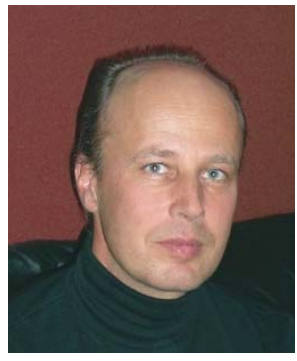

Vëndet në Europën Juglindore (EJL) janë të pasura me agregate ndërtimi p.sh gur i shtypur, zhavorr, rërë dhe inerte të tjera të grimcuara të cilat përdorën në industrinë e ndërtimit; megjithëatë këto resurse nuk janë të shpërnadara në mënyrë të barabartë përgjatë rajonit, duke bërë që disa rajone të jenë të mbingopura disa të tjera të kenë mungesa të theksuara. Për më tepër, aksesi në këto burime po behët më shume i vështirë për shkak të zhvillimeve infrastrukturore dhe presioneve lidhur me mjedisin. Duke qënë se agregatet janë të rënda transporti është i kushtueshëm, prandaj aksesi në tregjet lokale është tepër I rëndësishëm. Rajoni i EJL me shumë mundësi do të kërkojë 50 \% më shumë nxjerrje agregatesh deri në 2020, në mënyrë që ti përgjigjet kërkesave për infrastrukturë.

Rrjedhimisht, ekziston një nevojë për të kaluar në menaxhimin e qëndrueshëm të burimeve agregate (MQBA) dhe për të siguruar furnizim mix të qëndrueshëm (FMQ) të agregareve në rajon, në mënyrë që të rritet efiçensa e burimeve dhe të mbështetet zhvillimi i qëndrueshëm. MQBA është efikas, me impakt të vogël mjedisor i cili shoqërohet me një pjesmarrje më të gjerë të grupeve të interesit. FMQ përbëhet nga agregate të burimeve të ndryshme, përfshirë mbetjet e ricikluara nga ndërtimi dhe nen produktet industriale, sikundër dhe materialet e prodhura në vend apo ato të importuara, të cilat së bashku maximizojnë përfitimet nga oferta e agregateve përgjatë brezave.

Implementimi i MQBA dhe SSM kërkon politika mbështetëse dhe një kuadër planifikues. Për shkak të diferencave rajonale dhe zhvillimit historik, qasja ndaj politikës së agregateve, planifikimit dhe menaxhimit, ndryshon në plane të ndryshme në vendet e EJL. Sfidat përfshijnë menaxhimin e politikave dhe planeve që afektojnë agregatet, dhe garantimin e dokumentacionit ligjor të cilat e bëjnë koordinimin dhe kuptimin reciprok të vështirë. Gjithëashtu ka një mungesë bashkëpunimi lidhur me planifikimin e furnizimin e agregatëve parësore dhe dytësore. EJL ka mungesë të theksuar të dhënash për të mbështetur planifikimin e agregateve, kapacitete dhe kompetenca të pamjaftueshme për të adresuar palnifikimin e agregateve si primare ashtu dhe dytësore; vihet re dhe mungesë pjesëmarrje e grupeve të interesit në zhvillimin e planeve menaxhues. Projekti MQBA-EJL ka adresaur këto defiçite në mënyrë që të promovojë rritjen dhe zhvillimin e një industrie agregate të qëndrueshme dhe te përgjegjëshme në rajonin e EJL.

Qëlllimi specifik i Projektit të Planifikimit të Qëndrueshëm të Agregateve (PQA) në EJL është të krijojë dhe ofrojë një kuadër orientues për Planifikimin e Agregateve në mënyrë që të ndijmojë qeveritë dhe grupet e interest në EJL të bashkëpunojnë mes tyre, sa i takon proçesit të menazhimit dhe planifikimit. Projekti PQA është ndërtuar, bazuar në rezultat e Projektit Menaxhimit të Qndrueshëm të Resurseve Agregate (MQRA), një projekti i financuar nga Korporata Transkombëtare e EJL (http://www.sarma.eu). Projekti 
PQA-EJL është financuar nga EU South East Europe (SEE) Transnational Cooperation Programme (MQBA-EJL, SEE/D/0167/2.4/X) dhe ka 27 partnerë nga 12 vende të EJL dhe Turqia. Universiteti i Leoben në Austri, ishte partneri drejtues. Projekti PQA-EJL ishte një projekt 2 vjeçar i cili përfundoi në Nëndor të vitit 2014.

Projketi PQA-EJL në vetvete përmban 4 produkte të cilat janë të lidhura mes tyre, dhe mbështesin njëra-tjetrën.

\section{Një vizion i praktikave më të mira për Planifikimin e Agregateve në Europën} Jug Lindore

Dokumenti "Praktikat më të Mira" paraqet një vizion për kalimin në një planifikim të integruar, gjithëpërfshirës dhe të qëndrueshëm në EJL. Ai përfshin gjithashtu diskutime mbi çështje që duhen adresuar, hapa të ndërmjetën të cilat mund të ndërmerren drejt një planifikimi të qëndrueshëm, dhe një rishikim të komponentëve, që një plan i qëndrueshëm duhet të përmbajë.

2. Si të ndërtohet një Plan Agregatesh i Qëndrueshëm

Dokumenti "Si të" përfaqëson një hartë veprimesh për planifikimin, duke përfshirë diskutime për proçesin e planifikimit në vetvete dhe hapat e shumtë të tij. Shembuj të moduleve të planifikimit të shkruara mirë, janë hartuar në mënyrë, që të sigurojnë parimet, qasjet, dhe veprimet e nevojshme për të arritur objektivat dhe vizionin e përcaktuar në Raportin e Praktikave më të Mira.

3. Konsultimet me Grupet e Intersit gjatë aplikimit të Praktikave më të Mira në Planifikimin e Qëndrueshëm të Agregateve

Dokumenti i "Konsultimit" përmban një guide hap pas hapi për mënyrën e planifikimit dhe konsultimet me grupet e interest për të siguruar se industria, qeveria, organizatat jo fitimprurëse, dhe shoqëria civile, të thonë fjalën e tyre dhe të marrin pjesë në proçesin e planifikimit. Gjithashtu sigurohen materiale për rritjen e kapaciteteve.

4. Të dhëna dhe Analiza në mbështetje të Praktikave më të Mira në Planifikimin e Qëndrueshëm të Agregateve

Ky dokument diskuton tipet e ndryshme të të dhënave që sigurojnë informacionin thelbësor për proçesin e planifikimit. Në këtë dokument gjithashtu trajtohet përkufizimi, domethënia, vlefshmëria dhe struktura e të dhënave. Metodat për vleftësimin dhe analizimin e të dhënave paraqiten duke u përshtatur me parashikimin e kërkesës.

Koordinator Projekti

Guenter Tiess

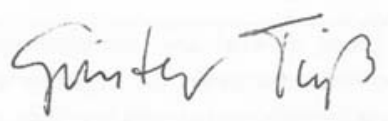

MontanuniversitätLeoben

(Universiteti i Leoben) 


\section{Informacion prezantues}

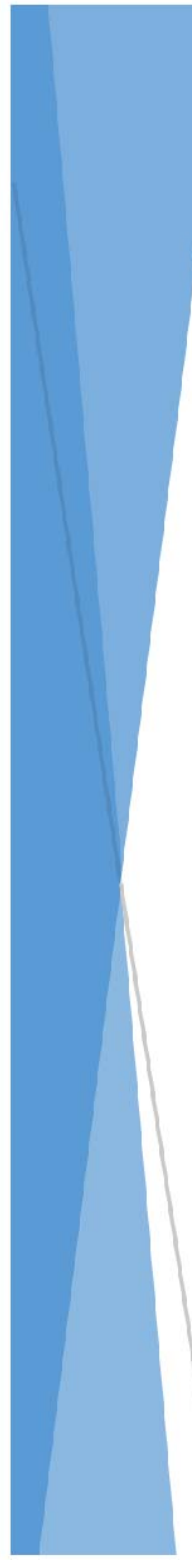

Të sigurosh një ofertë të qëndrueshme me agregate është një sfidë e rëndësishme nisur nga burimet e kufizuara natyrore që ekzistojnë. Për shkak të diferencave në zhvillimin historik të EJL, ka dhe qasje të ndryshme në politikat e agregateve, planifikimin dhe menaxhimin e tyre, gjë e cila pengon dhe zhvillimin ekonomik në rajon. Planifikimi i sukseshëm $i$ burimeve agregate dhe furnizimit me agregate parësore dhe dytësore, kërkon një gamë të gjërë informacioni mbështetës në mënyrë që të garantohet se çdo gjë po merret në konsideratë. Në të kundërt, objektivat e përcaktura në këtë plan, mund të jenë të vështira ose të pamundura për tu arritur, ose planet e hartuara bazuar në mungëse informacioni ose informacion të pasaktë mund të duken jorealiste dhe antiproduktive.Gjithëashtu rezulton se në shumicën e vendeve të EJL, agregatet dytësore nuk merren në konsideratë gjatë planifikimit të ofertës agregate, p.sh volume të shumta materialesh të nxjerra nga veprat civile nuk raportohen dhe për pasojë as nuk merren në konsideratë. Në mënyrë që planet e qëndrusheme agregate të mbështeten në plan kombëtar dhe rajonal, duhet të identifikohet i gjithë kuadri i të dhënave. 


\subsection{Nevoja për Planifikimin e Agregateve}

Agregatet (guri i thërmuar, rëra dhe zhavorri) janë material thelbësore për infrastrukturën rezidenciale, sociale, dhe tregtare të shoqërisë moderne Europiane. Europa aktualisht konsumon 3 miliardë ton agregate në vit, të cilat prodhohen nga rreth 26000 gurore. Konsumi në Europë varion nga 2 në 16 ton për frymë (UEPG, 2013). Tabela 1 tregon vlerësimin e konsumit për vendet e EJL e cila e ka mesataren

Table 1.1: Estimated SEE Region Tonnages (UEPG, 2013)

\begin{tabular}{|l|c|c|c|}
\hline & $\begin{array}{c}\text { Konsumi (milion } \\
\text { ton ) }\end{array}$ & $\begin{array}{c}\text { Popullata } \\
\text { (million njerëz) }\end{array}$ & Ton/Frymë \\
\hline Shqipëria & 10 & 3.2 & 3.1 \\
\hline $\begin{array}{l}\text { Bosnia - Her- } \\
\text { zegovina }\end{array}$ & 12 & 3.8 & 3.2 \\
\hline Bullgaria & 29 & 7.6 & 3.8 \\
\hline Kroacia & 13 & 4.4 & 3.0 \\
\hline Greqia & 25 & 11.3 & 2.2 \\
\hline Hungaria & 36 & 10.0 & 3.6 \\
\hline Maqedonia & 6 & 2.0 & 3.0 \\
\hline Mali i Zi & 2 & 0.6 & 3.3 \\
\hline Rumania & 96 & 22.0 & 4.4 \\
\hline Serbia & 17 & 7.3 & 2.3 \\
\hline Sllovakia & 23 & 5.4 & 4.3 \\
\hline Sllovenia & 9 & 2.0 & 4.5 \\
\hline Total/Mesatare & 278 & 79.6 & 3.5 \\
\hline
\end{tabular}

3.5 ton për frymë.

Rreth 90 \% të Agregateve vijnë nga depozita natyrore, ndërsa $10 \%$ e tyre vijnë nga materiale të ricikluara, detare apo të fabrikuara. Prodhimi i këtyre të fundit do të vazhdoje të rritet, megjithëatë në terma afatgjatë $85 \%$ e kërkesës do të kënaqet nga burimet natyrore. Duke qënë se agregatet janë materiale të rënda, burimet e tyre duhet të jenë afër qëndrave të konsumimit, si për arsye ekonomike ashtu dhe mjedisore. (Leoben, 2010).

Figura 1.1 paraqet lidhjen mes Prodhimit të Brendshëm Bruto (GDP) për frymë, për të gjitha vendet Europiane dhe konsumit agregat për frymë. Qartazi, konsumi i agregateve rritet me rritjen e GDP, dhe rrjedhimisht konsumi në vendet EJL pritet të rritet në vitet e ardhshme së bashku me rritjen e GDP. 


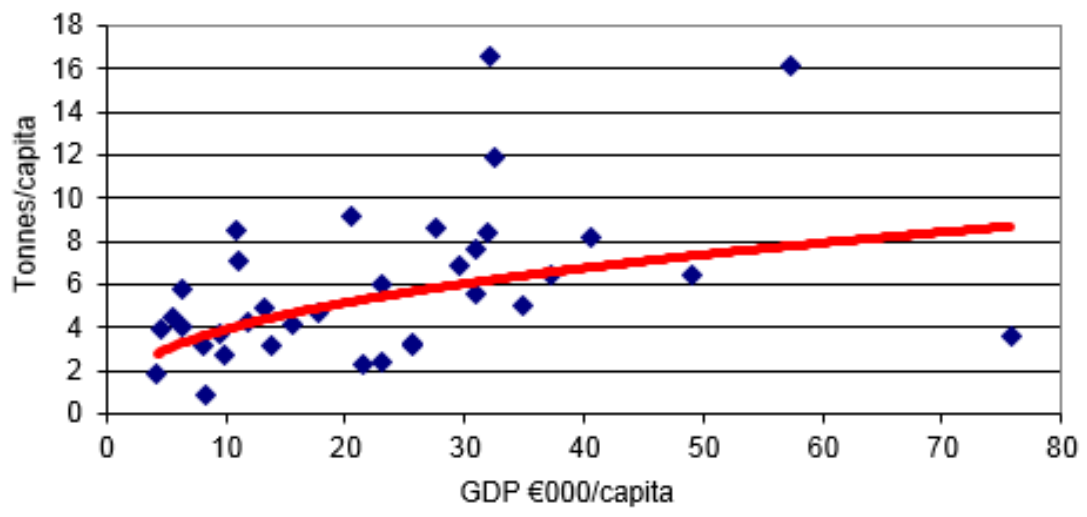

Figura 1.1: GDP për frymë vs. Ton për Frymë për të gjitha vendet Europiane (UEPG 2013)

\subsection{Qëllimi dhe Struktura e Manualit}

Ky manual fokusohet te të dhënat në vetvete dhe metodologjia e të dhënave, e cila nevoitet për te arritur planifikim të qëndrueshëm të agregateve, duke ofruar një kuadër të dhënash efikase të cilat mbështesin menaxhimin efektiv të burimeve të agregateve primare dhe sekondare. Figura 1.2 përfaqëson një diagramë të thjeshtëzuar të zinxhirit të kërkesës dhe ofertës lidhur me planifikimin e qëndrueshëm të agregateve. Planifikimi ofertës apo furnizimi i agregateve është një aktivitet të cilin e kryen qeveria, dhe objektivi i saj është të përcaktojë politikat, bazën ligjore, veprimet dhe informacionin që nevoitet për të siguruar sasitë e duhura të agregateve parësore dhe sekondare në ekonominë kombëtare dhe rajonale, në terma afatshkurtër, afatmesëm dhe afatgjatë.

Disa vlerësime të përgjithshme janë paraqitur në kapitullin 2, dhe koncepti i një matrice informacioni do të prezantohet në kapitullin 3. Kapitulli 4 fokusohet në grupimet e të dhënave që nevoiten në çdo fushë pjesëmarrje, ndërsa kapitulli 5 paraqet metodologjitë e anazlizimit të të dhënave për llogaritjen e kërkesës agregate.

\subsection{Përkufizimi i termave të përzgjedhur}

Shumica e përkufizimeve të referuara në këtë tekst, nësë nuk sqarohen ndryshe, bazohen në fjalorin e zhvilluar gjatë projektit MQBA 2011 (shih parathënien).

\section{Agregate}

Material i grimcuar ose thërmuar, i nxjerrë nga natyra (rëra ose zhavorri) ose i prodhuar nga thërmimi i gurit/shkëmbit, i cili kur bashkohet me çimenton, gëlqeren 
apo bitumin, përdoret për të formuar një masë të vetme të një ndërtimi ose

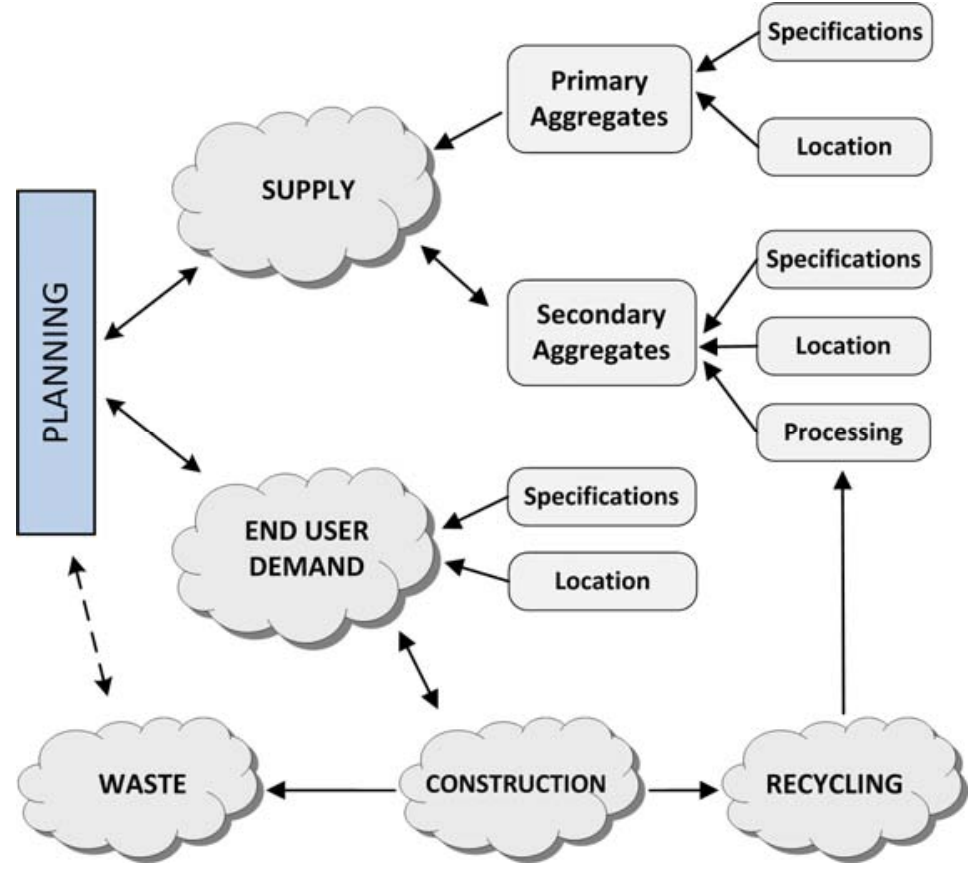

strukture inxhinierike. Gjithëashtu referohet si "Agregate Ndërtimi" dhe përdoret kryesisht si beton, llaç, asfalt, rrugë kullimi, ose çakëll hekurudhe.

\section{Planifikim Agregat}

Politikat e planifikimit të agregateve janë deklaruar objektiva qeveritar në fushën e agregateve. Planifikimi konsiston në krijimin e proçedurave formale të cilat duhet të ndiqen për të arritur objektivat; dhe menaxhimi i planifikimit ka të bëjë me administrimin e proçedurave.

\section{Konsumi agregateve}

Konsumi i dukshëm i agregateve përllogaritet nga të dhënat e shitjeve në çdo rajon (ose nën-rajon), plus importet e deklaruara nga rajonet të tjera (ose nën-rajone), dhe nëse është e aplikueshme imprortet e deklaruara nga vendet e tjera. Shitjet e paalokuara me destinacion të panjohur nuk mund ti atribohen konsumit rajonal (ose nën-rajonal). Më tej, duhet të tregohet kujdes në interpretimin e shifrave të konsumit pasi ato kalkulohen vetëm duke mbajtur në konsideratë destinacionin fillestar të qarkullimit të agregateve. (Ëelsh Assembly Government, 2011). 


\section{Anketimi i Mineraleve Agregate}

Anketimi i Mineraleve Agregate është një anketë vullnetare mbi prodhimin dhe rezervat, e cila ndërmerret çdo disa vite ( $p . s h$ cdo 4 ose 5 vite). Rezultatet e anketimit janë tepër të rëndësishme për politikat e zhvillimit, planifikimit dhe furnizimit me agregate. (BGS, 2014a).

\section{Shitjet e Agregateve}

Sasia në ton e mineralit, e cila lë guroret dhe matet në urën e peshimit (Ëelsh Assembly Government, 2011).

\section{Autoriteti}

Koncepti i "Autoritetit" është trajtuar gjërësisht në jurisprudencën e Gjykatës Europiane të Drejtësisë (GJED). Ky koncept mund të përkufizohet si një trup, i cili pavarësisht formës (Kombëtar, rajonal apo lokal), kompetencave, është i ngarkuar nga Shteti për të ofruar një shërbim publik nën kontrollin e shtetit, dhe për këtë qëllim është i ngarkuar me tagra të posaçme. (SEA, 2001).

\section{Gropat e përkohëshme}

Një vënd për nxjerrjen e agregave për një periudhë të shkurtër kohe, e cila do të përdoret në mënyrë ekskluzive për projekt ndërtimi, e cila më vonë do mbyllet. (Ëelsh Assembly Government, 2011).

\section{Kërkesa}

Kërkesa është nevoja apo dëshira për të poseiduar një mall apo shërbim me mjetet e duhura financiare për të kryer transaksoinin ligjore për mallrat apo shërbimet në fjalë.

\section{Parashikimi i Kërkesës}

Kërkesa e përllogaritur apo e pritshme për një periudhë të caktuar kohe.

\section{Plan zhvillimi}

Planet e zhvillimit identifikojnë nevojat demografike, ekonomike, mjedisore dhe sociale të zonës dhe më pas përcaktojnë strategjinë afatgjatë për ti trajtuar ato. Për mineralet, objektiv strategjik është të parashikohen politika dhe alokime tokash që nuk ndalojnë punën me mineralet dhe njëherazi akomodojnë interesat mjedisore të shoqërisë. Vlerësimi Strategjik Mjedisor (VSM) i planeve të zhvillimit do të garantojë shqyrtimin rigoroz të pasojave mjedisore të strategjisë së zhvillimit.

\section{Mbetjet nga nxjerrja e mineraleve}

Mbetjet që vijnë nga kërkimet, nxjerrja, trajtimi apo përpunimi dhe ruajtja e burimeve minerale dhe guroreve. 


\section{Fondi i tokës}

Një stok lejesh planifikimi për rezerva, të cilat sigurojnë vijimësi prodhimi për një numër të caktuar vitesh (BGS, 2014a).

\section{Planifikimi i përdorimit të tokës}

Një aktivitet, i udhëhequr zakonisht nga qeverisja lokale parashikon rekomandime për përdorimin publik apo privat të tokës, në mënyrë që ky përdorim të jetë konsistent me nevojat dhe preferencën e publikut. Zakonisht përdoret për të orientur vendimet mbi zonat e caktuara.

\section{Vlerësimi Ciklit Jetësor (VCJ)}

Vlerësimi i ciklit jetësor është një investigim lidhur me impaktin mjedisor të produktit, përgjatë gjithë ciklit të jetës. Pas këtij vlerësimi analizon proporcionin mes impaktit në mjedis dhe kostos monetare.

\section{Agregatet e prodhuara}

Agregatet e prodhuara nga aktivitete industriale, apo përpunimi dhe ripërpunimi $i$ mbetjeve.

\section{Analiza e Fluksit të Materialeve (AFM)}

Analiza e fluksit të materialeve i referohet monitorimit dhe analizës së fluksit fizik të materialeve brenda dhe jashtë një sistemi të caktuar (zakonisht ekonomija) përmes proçeseve zinxhirë si nxjerrja, prodhimi, përdorimi, riciklimi dhe tjetërsimi. AFM zakonisht bazohet ne llogari metodologjike të ndara në njësi. Termi AFM është një mënyrë për të përcaktuar një familje mjetesh që përmban një gamë të gjërë njësishë, indikatorësh dhe metoda vlerësimi në nivele të ndryshme ambicjesh, detajesh dhe plotesimesh.

\section{Autoriteti i Planifikimit Mineral}

Autoriteti përgjegjës për planifikimin e kontrollit dhe zhvillimit të mineraleve. Autoritetet e planifikimit të mineraleve janë autoritetet trupat ligjore (këshillat e rethit, këshillat komunal, autoritetet kombëtare, etj) të cilat kontrollojnë punimet minerale në zonat e tyre. Atyre u jepen udhëzime nga qeveria në formën e strategjive rajonale. (BGS, 2014a).

\section{Burimet minerale}

Përkufizohen si përqëndrime natyrore me minerale, ose, në rastin e agregateve, formacione shkëmbore të cilat kanë, ose mund të kenë interes ekonomik për shkak të karakteristikave të tyre të natyrshme. Minerali do të jëtë i pranishëm në sasi të mjaftueshme për ti dhënë interes ekonomik të brendshëm. (BGS, 2014b). 


\section{Rezervat minerale}

Ajo pjesë e burimeve natyrore, e cila është vlerësuar plotësisht dhe është konsideruar e leverdisëshme nga ana ekonomike, dhe ka një leje të vlefshme shfrytëzimi. Rezervat duhet të plotësojnë jo vetëm kërkesat për siguri gjeologjike dhe ekonomike, por dhe ato ligjore për nxjerrjen dhe shfrytëzimin e tyre. Rrjedhimisht, në kontekstin e planifikimit të përdorimit të tokës termi rezervë minerale duhet te kufizohet vetëm te ato minerale me të drejtë ligjore përdorimi, për të cilat janë dhënë lejet e posaçme. Rezervat agregate janë të një rëndësie themelore në proçesin e planifikimit, në mënyrë që të sigurohet një furnizim i plotë dhe i duhur për të përballuar nevojat e shoqërisë me agregate (BGS, 2014c).

\section{Agregate natyrore}

Agregate nga burime minerale të cilat nuk $\mathrm{i}$ janë nënshtruar asnjë proçesi tjetër veç atij mekanik.

\section{Rezerva të lejuara}

Depozita minerale me të drejtën e lejes për gërmim (BGS, 2014a).

\section{Kushtet e planifikimit}

Kërkesat e bashkëlidhura pas lejes së planifikimit për të kufizuar apo drejtuar mënyrën në të cilën zhvillimi do të kryhet (BGS, 2014a).

\section{Leja e planifikimit}

Aprovimi formal i kërkuar nga një këshill, shpesh i aprovuar me kushte, i cili lejon një zhvillim të propozuar të proçedojë. Leja mund të kërkohet në parim përmes një plani pjesor, apo në detaje përmes një plani të plotë (BGS, 2014a).

\section{Agregatet parësore}

Agregate të prodhura nga depozita natyrore, të cilat nxirren enkas për përdorim si agregat (BGS, 2014a).

\section{Agregate të ricikluara}

Agregate të përfituara nga riciklimi i mbetjeve të ndërtimit apo i ndërtesave të shkatërruara. "Përqindja e Ricikluar" përllogaritet si përqindja e materialeve të ndërtimit dhe ndërtesave të shkatërruara që është e vlefshme për riciklim.

1. Agregatet e derivuara nga mbetjet e ndërtimit si p.sh tulla të dëmtuara, dhe mbetjet e ndërtesave të shkatërruara p.sh beton e i thyer, muratore etj.

2. Agregate të derivuara nga përpunimi i materialeve inorganike të përdorura më parë në ndërtim. 


\section{Rezerva}

Shih rezervat minerale

\section{Burime}

Përqëndrim i një grupi mineral, lokaliteti, grada, cilësia dhe sasia e të cilit është e matshme, e ditur apo e përllogaritur nga fakte specifike gjeologjike.

\section{Efikasiteti i burimeve}

Një praktike në të cilën përdorimi primar i materialit fillon me konceptin "ZvoglëRipërdor-Riciklo-Riparo" sipas rendit zbritës.

\section{Liçensë sociale për të operuar}

Liçensa Sociale për të Operuar (LSO) i referohet perceptimeve të grupet të interesit nëse një kompani, projekt apo industri që operon në një zonë të caktuar është $i$ pranueshëm nga pikpamja sociale. Meqënëse një liçensë në kuptimin ligjor i referohet një dokumenti të lëshuar nga një entitet ligjor, p.sh një qytet, shtet/provincë, ose qeveria qëndrore dhe jep autorizimin për të ndërtuar, operuar bazuar në parametra financiar dhe hapsiror, liçensa sociale nga ana tjeter i referohet një forme tjetër marrëveshje mes kompanisë dhe partnerëve lokal (Springer 2014).

\section{Menaxhimi i Qëndrueshëm i Burimeve Agregate (MQBA)}

MQBA është shfrytëzimi dhe menaxhimi i mineraleve me një impakt sa më të vogël socio-mjedisor. MQBA lidhet në mënyrë direkte me shfrytëzimin dhe guroret. Në këtë kuptim burimet e mundëshme të agregateve sekondare nuk janë të përfshira.

\section{Furnizimi i Qndrueshëm Mix (FQM)}

FQM do të thotë që kërkesa për agregate duhet të përmbushet me një kombinim të agregateve primarë dhe sekondarë në mënyrë që të maksimizohen benefitet neto të furnizimit me agregate përgjatë brezave.

\section{Agregatet Sekondare}

Agregatet të cilat kanë si origjinë mbetjet e operacioneve minerale, ose që vijnë nga një proes industial (p.sh mbetjet nga një minierë qyrmyrguri, material shllaku të nxjerra nga furra, hirit të një çentrali elektrik, mbetje ndërtimi apo ndërtimesh të shkatërruara) por duke përjashtuar këtu argjilën e punuar për qëllime agregate.

\section{Planifikimi i hapsirës}

Planifikimi i hapsirës shkon përtej planifikimit tradicional të përdorimit të tokës, për të bashkuar dhe integruar politikat e zhvillimit dhe të përdorimit të tokës sëbashku me politika dhe programe të tjera që influencojnë natyrën e vendeve dhe mënyrën si 
funksionojnë. Kjo do të përfshinte politika që mund te kenë impakt në përdorimin e tokës, p.sh duke influencuar kërkesat, apo nevojat për zhvillim, të cilat nuk arrihen vetë ose përmes dhenies së thjeshtë një leje planifikimi (BGS, 2014a).

\section{Vlerësimi strategjik mjedisor}

Vlerësimi mjedisor i planeve apo programeve të caktura, përfshirë ato në fushën e planifkimit të përdorimit të tokës, të cilat janë në përputhje me Direktivën e Bashkimit Eurpian 2001/42/EC. Vlerësimi mjedisor përfshin: përgatitjen një raporti mjedisor; ndërmarrjen e konsultimeve; mbajtjen në konsideratë të raportit mjedisor dhe rezultateve të konsultimeve gjatë vendim-marrjes; sigurimin e informacionit kur programi të implementohet; dhe të tregohet se rezultatet e vlerësimit mjedisor janë mbajtur në konsideratë (BGS, 2014a).

\section{Oferta}

Sasia e produktit (mall apo shërbim) e vlefshme për të blerë me çmim të përcaktuar. Oferta përcaktohet nga të dhënat e çmimit. Çmimi përcaktohet nga ndërveprimi i kërkesë-ofertës.

\section{Zhvillimi i qëndrueshëm}

Zhvillimi që përmbush nevojat e së tashmes pa kompromentuar aftesitë e brezave të ardhshëm për të përmbushur nevojat e veta.

\subsection{Kategoritë e agregateve}

\subsubsection{Agregatet primare}

Agregatet Primare prodhohen pas përpunimit mekanik të materialeve të para minerale të nxjerra për përdorim specifik nga guroret apo minierat. Ato mund të jenë rërë, zhavorr apo gur i rëndë. Në disa raste përfshihen dhe agregatet detare (Fig 1.3).

\subsubsection{Agregatet Sekonare}

Termi "agregate sekondare" përdoret për të përshkruar agregatet që kanë si origjinë mbetjet që ngelin nga operacionet minerare, apo nga proçeset indstriale (p.sh mbetjet nga një minierë qyrmyrguri, material shllaku të nxjerra nga furra, hirit të një çentrali elektrik, mbetje ndërtimi apo ndërtimesh të shkatërruara) por duke përjashtuar ketu shkumësin dhe argjilën e punuar për qëllime agregate (Fig 1.3).

Agregatet primare përbëjnë produkte shfrytëzimi të burimeve natyrore të pa riciklueshme, dhe rrjedhimisht kërkohet përdorim racional i tyre me qëllim që të zgjatet jetëgjatësia e rezervave. Një nga mënyrat për ta arritur këtë objektiv është ti 
ofrohen tregut, materiale alternative. Në këtë kontekst, është politikë e qeverisjes të zvogëlojë kontributin e agregateve nga burime tokësore, duke inkurajuar përdorimin e gjërë të alternativave të tjera, konkretisht agregatet e ricikluara dhe sekondare. Kur është e mundur, autoritetet planifikuese duhet të identifikojnë volumin e burimeve sekondare që mund të përdoren si agregate. Në veçanti, përdorimi i agregateve të ricikluara (R2) (Fig. 1.3) është rritur duke qënë se një numër vendesh kanë përshtatur objektivat dhe politikat e tyre duke i planifikaur ato. Agregatet e ricikluara mund të ndihmojnë të plotësohet kërkesa për agregate dhe dhe njëkohësisht të ulin nevojën për agregatet primare, përmes ri-përdorimit të agregateve që mund të hidheshin nëse nuk përdoren në këtë mënyrë.

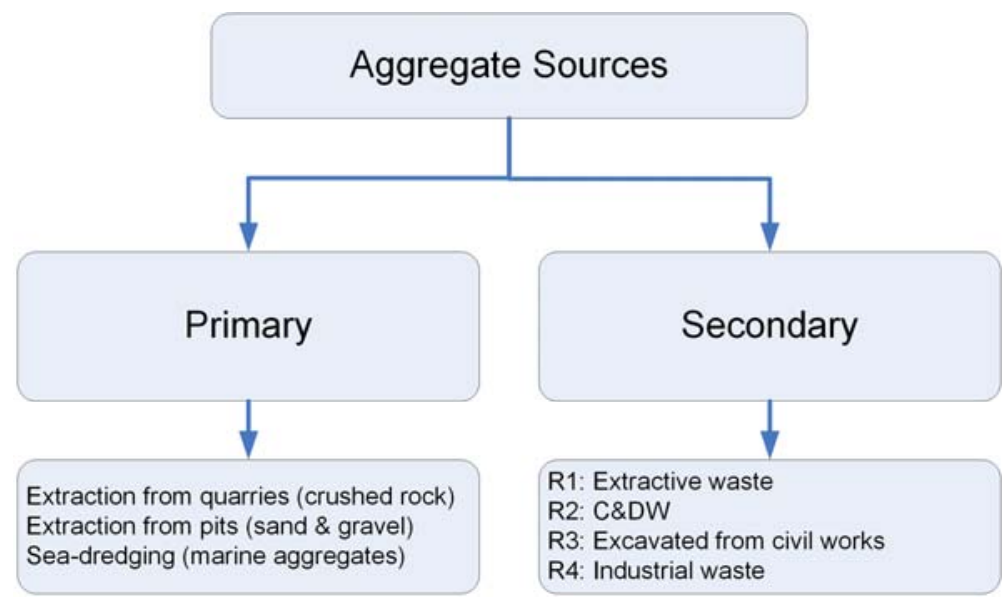

Figura 1.3: Klasifikimi i burimeve të mundshme agregate 


\section{Domethënia e Planifikimit të të Dhënave dhe Metodave Analitike}

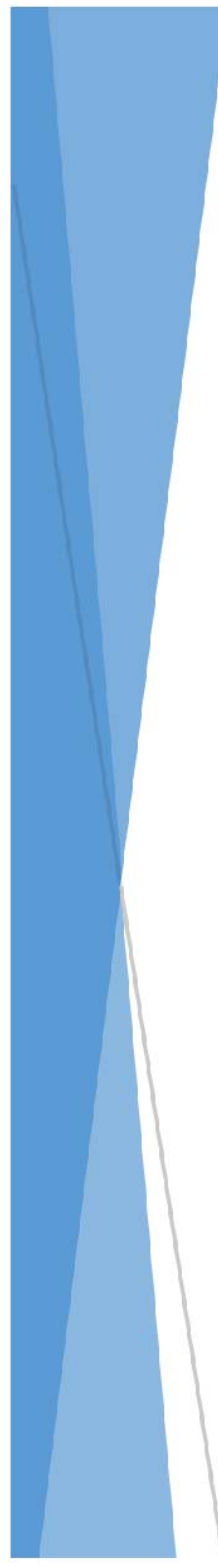

Vlefshmëria e grupeve të të dhënave, që të jenë të sakta dhe të aksesueshme në çdo kohë është një nga komponentët kryesor për të pasur një planifikim të sukseshëm në çdo nivel. Autoritetet planifikuese në të gjitha nivelet duhet të kenë akses në rezervat e lejuara, në kapacitetet vjetore për të prodhuar si agregate primare ashtu dhe dytësore (kurdo që të jënë të vlefshme në zinxhirin mix të furnizimit), në mënyrë $q \ddot{~}$ të menaxhohen me sukses nevojat aktuale të industrisë së ndërtimit për veprat infrastrukturore të ardhshme, si p.sh ndërtimi i rrugëve apo urave. 


\subsection{Vlerësime të përgjithshme}

Planifikimi i agregateve arrihet në nivel kombëtar, rajonal apo lokal, në varësi të nivelit të deçentralizimit të çdo vendi. Është e një rëndësie të veçantë caktohen kufijte e zonës që do të shfrytëzohet, gjatë proçesit të planifikimit të agregateve. Nëse proçesi i planifikimit nuk është përcaktuar ende, siç ndodh në shumicën e vendeve të EJL, atëhere nevoiten një numër hapash përgatitor përpara fillimit të planifikimit (Fig 2.1). Një proçes planifikimi duhet të ndjeki të njëjtat parime si në proçesin e Menaxhimit të Qëndrueshëm të Burimeve Agregate (MQBA) dhe të Furnizimit të Qëndrueshëm Mix (FQM). MQBA parashikon një kuadër për zhvillimin e politikave të menaxhimit të resurseve në mënyrë që të maksimizohen kostot e furnizimit me agregate.

Duhet theksuar se kuadër politike kombëtare për agregatet, nëse ekziston, duhet të parashikojë një deklaratë për mineralet, objektivat, strategjinë dhe një plan veprimesh. Një politkë për MQBA influencon zhvillimin e tregjeve agregate bazuar në mjete dhe instrumente të ndryshme. Për shembull, duke ofruar koncepte që lidhen me transportin efikas të agregateve, p.sh duke ngushtuar distancat e transportit përmes mjeteve të ndryshme (taksat $\mathrm{CO}_{2}$ ). Furnizimi i Qëndrueshëm Mix FQM përdor burime të shumta, përfshirë dhe mbetjet e ricikluara dhe nënproduktet $\mathrm{e}$ industrisë, të cilat së bashku maximizojnë përfitimet më agregate përgjatë brezave.

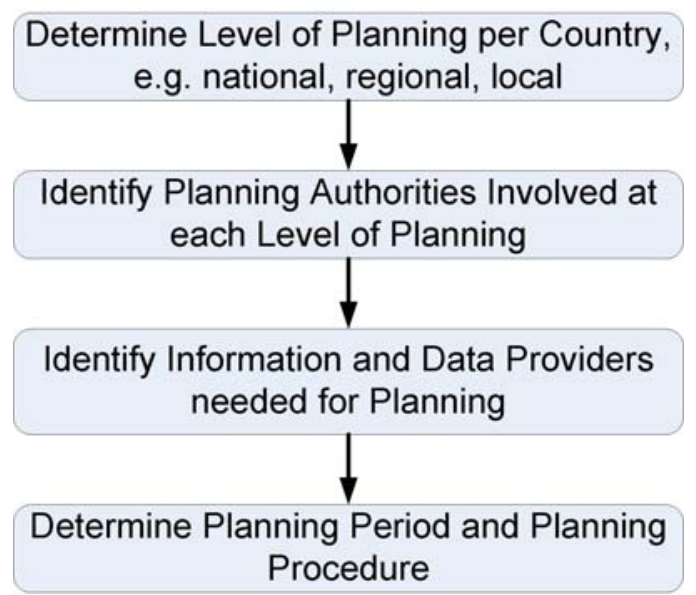

Figura 2.1: Hapat e nevojshëm përgatitor për planifikimin e agregateve 
Korniza e politikës MQBA përcakton njëherazi planifikimin e FQM (p.sh politikat e planifikimit të agregateve bazuar në planifikimin e përdorimit të tokës) si dhe kuadrin rregullator të FQM.

Planifikimi i FQM lidhet me proçesin e planifikim/zhvillimit nga autoritetet/grupet e interesit përkatës, duke përdorur këto burime të shumëllojshme në mënyrë që të sigurojnë një ofertë apo furnizim të qëndrueshëm agregatesh. Në përgjithësi, ky lloj planifikimi, nuk është plotësisht i zhvilluar në shumë vende/rajone të vendeve të EJL. Një aspekt themelor i politikës MQBA dhe FQM (p.sh planifikimi i qëndrueshëm) është menaxhimi i të dhënave. Në mungesë e të dhënave të sakta dhe të plota, por dhe proçedurave analitike realiste politika e planifikimit nuk mund të aplikohet.

Në shumicën e vende të EJL çështjet që lidhen me agregatet primare (për momentin) janë të menaxhuara veçmas nga çështjet e lidhura me burimet sekondare; kjo e bën planifikimin e FQM tepër sfidues. Aplikimi i politikave të FQM do të thotë që kërkesa për agregate duhet të plotësohet përmes një kombinimi të agregateve primare dhe sekondare, të cilat sëbashku i maximizojnë fitimet e furnizimit me agregate përgjatë brezave. Të gjithë grupet e interesit, p.sh, ato që janë përgjegjës për planifikimin e përdorimit të tokës ose për rregullimin e procesit të planifikimit të agregateve të ricikluara dhe përdorimin e qëndrueshëm të burimeve natyrore, si dhe të industrisë, komunitetit lokal, OJF, dhe shoqëria civile, duhet të bashkëpunojnë ngushtësisht (Fig. 2.2). Korniza e politikës FQM parashikon "rregullat bazë të operimit" për industrinë e agregateve primare dhe sekondare.

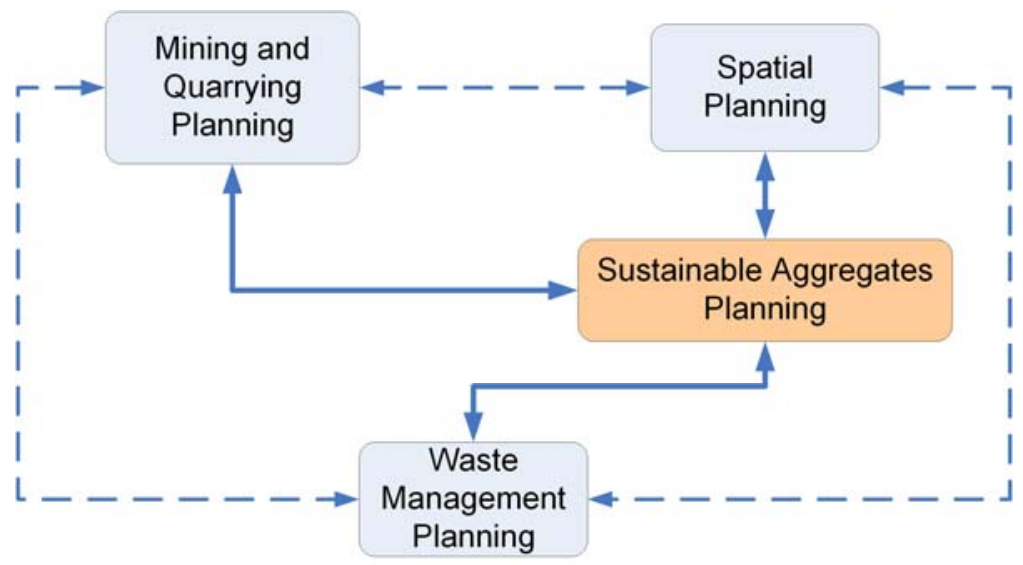

Figura 2.2: Planifikimi i agregateve varet nga përpjekjet e të tjerëve për planifikim 


\subsection{Rëndësia e të Dhënave për Planifikim të Qëndrueshëm}

Në terma të thjeshtë, gjatë planifikimit të agregateve duhet tu jepet përgjigje këtyre dy pyetjeve: (a) Sa material agregat nevoitet për të mbuluar nevojat për konsum të një zonë të caktuar për një periudhë të caktuar dhe (b) sa agregate primare apo sekondare janë të vlefshme në atë zonë?

Është evidente se një sasi e madhe e të dhënave të ndryshme, si psh hartat, figurat, statistikat, legjislacioni, nevoitet për t'i dhënë përgjigje atyre pyetjeve. Marrja e këtyre të dhënave është pjesë e përpjekjeve që autoritetet planifikuese duhet të ndërmarrin në mënyrë që të përpilojnë qoftë edhe një plan të thjeshtë për agregatet. Pjesa tjetër përfshin të gjitha aktivitetet për menaxhimin e të dhënave, p.sh vlerësimi i të dhënave, analiza dhe krahasimi i të dhënave të vjetra me ato të reja, etj. Për më tepër, një planifikim i qëndrueshëm i agregateve kërkon përfshirjen e metodologjive të ndryshme si p.sh analiza e ciklit të jetës në mënyrë që të vlerësohet cila është zgjidhja më e mirë, mes shumë alternativave. Nevoja për njohuri integrale të dispozitave që do hartohen, si te ato aktuale ashtu dhe te ato që po përgatiten, duhet të shtohet si një rekuizit për çdo planifikim, politikë apo aktivitet realist.

Është evidente se një sasi e madhe e të dhënave të ndryshme, si psh hartat, figurat, statistikat, legjislacioni, nevoitet për t'i dhënë përgjigje atyre pyetjeve. Marrja e këtyre të dhënave është pjesë e përpjekjeve që autoritetet planifikuese duhet të ndërmarrin në mënyrë që të përpilojnë qoftë edhe një plan të thjeshtë për agregatet. Pjesa tjetër përfshin të gjitha aktivitetet për menaxhimin e të dhënave, p.sh vlerësimi i të dhënave, analiza dhe krahasimi i të dhënave të vjetra me ato të reja, etj. Për më tepër, një planifikim i qëndrueshëm i agregateve kërkon përfshirjen e metodologjive të ndryshme si p.sh analiza e ciklit të jetës në mënyrë që të vlerësohet cila është zgjidhja më e mirë, mes shumë alternativave. Nevoja për njohuri integrale të dispozitave që do hartohen, si te ato aktuale ashtu dhe te ato që po përgatiten, duhet të shtohet si një rekuizit për çdo planifikim, politikë apo aktivitet realist.

Informacioni i nevojshëm në skemën e mbledhjes së të dhënave për agregatet primare duhet të përfshijë karakteristikat tipike të këtyre agregateve si psh, origjina, përbërja, elementet mekanik, etj. Më të rëndësishme janë të ashtuquajturat "rezerva të lejuara", rezerva për të cilat të gjitha fazat për marrjen e lejes së shfrytëzimit janë marrë, dhe për pasojë mund të përdoren menjëherë. Burimet e pa lejuara marrin kohë të konsiderueshme për tu maturuar në rezerva të lejuara, prandaj mund të konsiderohen si potencialisht të vlefshme për tu përfshirë në rrjedhë. Për më tepër rrugët për tu futur ne agregatet sekondare apo të ricikluara janë të ndryshme. Shumica e vendeve të EJL nuk e kanë shfrytëzuar këtë mundësi akoma. 


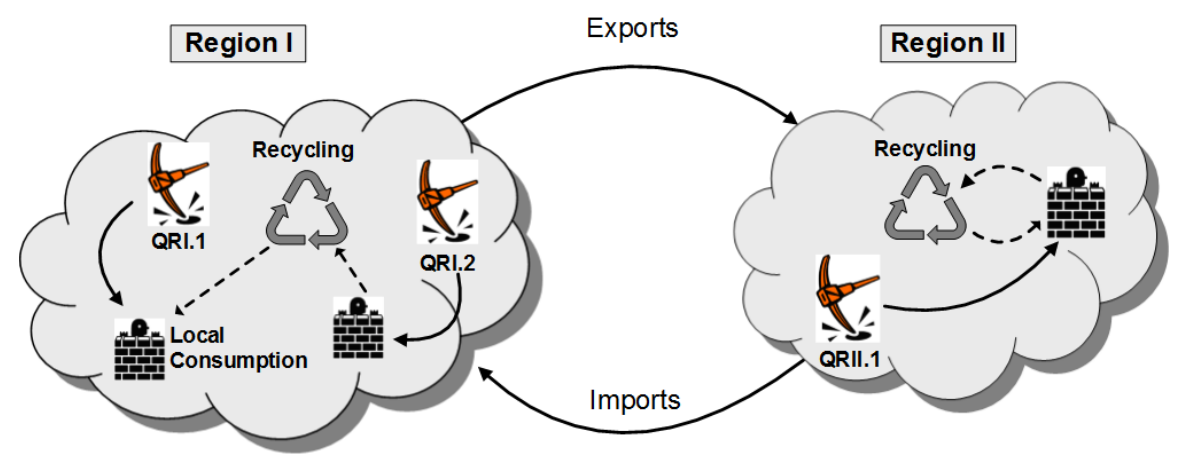

Figura 2.3: Një rast tipiki qarkullimit të materialeve brenda dhe ndërmjet rajoneve fqinje

Pavarësisht karakteristikave teknike dhe vlefshmërisë në hapsirë të agregateve, planifikimi i sukseshëm duhet të konsiderojë indicje të tjera siç janë rritja e popullatës, potenciali ekonomik në rajon, etj.

Këto të dhëna do të nevoiten për të përllogaritur modelet e kërkesës në të ardhmen, modelet e vlerësimit të ciklit të jetës, fluksit të materialeve dhe paradigmat sociale. Analizat e rezultateve duhet të përdoren në kombinim me burimet e vlefshme, dhe me autoritetet e planifikimit të tokës në mënyrë që ti mundësohet atyre $i$ gjithë informacioni për marrjen e vendimeve lidhur me planifikimin e qëndrueshëm të agregateve. Kjo do të çonte në një përdorim efikas të burimeve natyrore dhe në përputhje me kërkesat ambjentale të rajonit, dhe rajoneve fqinje. Figura 2.3 tregon një rast tipik të qarkullimit brenda dhe ndërmjet rajoneve fqinjë.

\subsection{Vlefshmëria e të dhënave në vendet/rajonet e EJL}

Në mënyrë që të identifikohen të dhënat e vlefshme për planifikimin e agregateve primare dhe sekondare për çdo vend/rajon në këtë projekt për EJL, u hartua një pyetësor. Partnerët e këtij projekti siguruan informacion mbi vlefshmërinë e të dhënave, burimet dhe përdorimin për të mbështetur planifikimin e qëndrueshëm të agregateve në rajonet apo vendet përkatëse. Gjithëashtu, çdo partner u pyet që të përcaktone shkallën në të cilënt këto të dhanë janë të vlefshme në 13 vendet/rajonet, nën juridiksionin e kujt është marrja e tyre, dhe nëse ato po përdoren aktualisht për planifikim. Më specifikisht, çështjet që u ngritën në pyetësor lidhen me:

$\checkmark \quad$ Të dhënat që konsiderohen të rëndësishme për planifikimin e agregateve;

$\checkmark \quad$ Të dhënat që mungojnë apo që nuk po mbahen aktualisht në konsideratë; 
$\checkmark$ Shkalla e vlefshmërisë, saktësisë dhe e problemeve të hasuara që influencuan marrjen e të dhënave dhe saktësine e tyre;

$\checkmark \quad$ Agjensinë përgjegjëse për mbledhjen, ruajtjen, raportimin dhe rifreskimin e të dhënave;

$\checkmark \quad$ Formatin në të cilin të dhënat janë të vlefshme;

$\checkmark \quad$ Nivelin e detajeve të të dhënave dhe burimeve të tyre;

$\checkmark \quad$ Metodat e analizimit të të dhënave që përdoren për ti konvertuar ato në të dhëna të përdorshme dhe në funksion të planifikimit agregat.

Siç u konkludua pas shqyrtimit të pyetësorëve, shumica e vendeve/rajoneve të EJL mbajnë arshiva dhe harta mbi shpërndarjen e agregateve primare dhe rezervave të lejuara, në vendodhjen e gërmimit, cilësinë, dhe mbi sasinë e prodhuar. Ndërkohë që të dhëna mbi përllogaritjen e kërkesës dhe të dhënave mbi konsumin e agregateve janë të vlefshme vetëm në disa vende. Në shumicën e vendeve/rajoneve të EJL pjesa më e madhe e të dhënave janë të ruajtura në bazë të dhënash dixhitale (Fig. 2.4).

Informacioni kyresor gjeologjik lidhur me shpërndarjen e burimeve të agregateve primarë (p.sh., hartat gjeologjike nga shkalla 1:50.000 në 1:100.000, vendndodhja në hartë e minierave funksionale apo të braktisura, një vlerësim i gjërë i cilësisë së

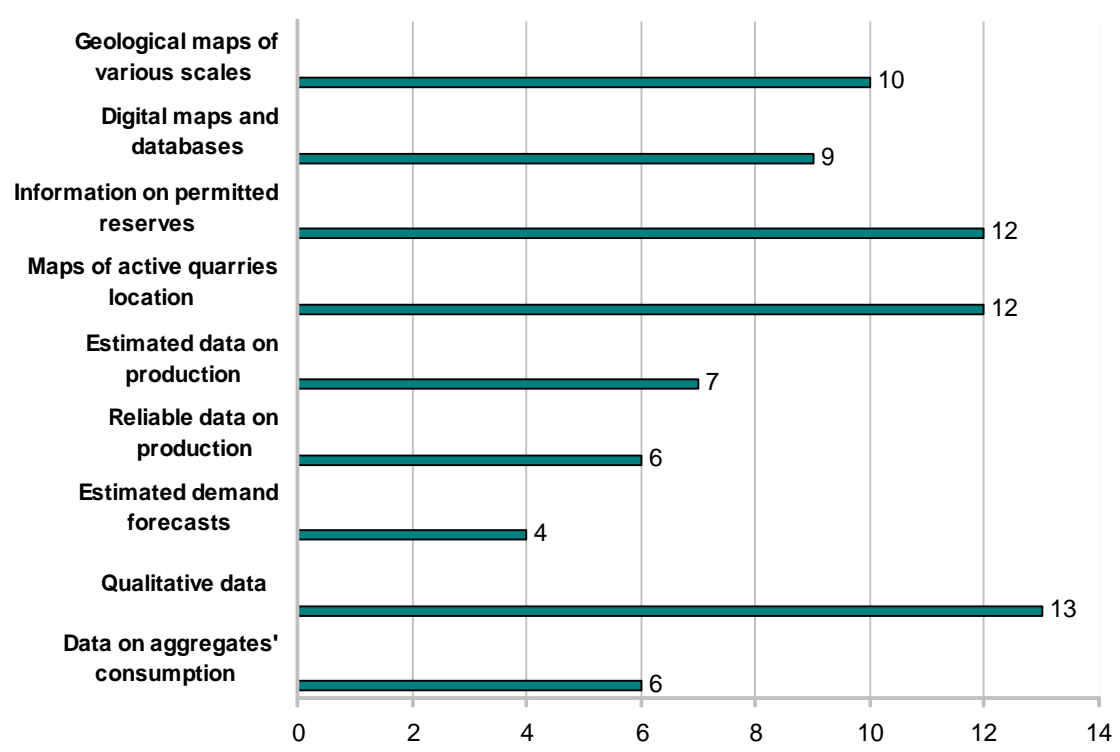

Figura 2.4: Vlefshmëria e të dhënave sipas kategorisë në 13 vendet apo rajonet e Europës Jug Lindore (EJL) (Hatzilazaridou, 2014) 
burimeve etj) zakonisht sigurohen nga shërbimi gjeologjik kombëtar i vendit.

Të dhënat mbi rezervat e lejuara, prodhimin dhe aftësitë prodhuese të punimeve minerare, cilësia, shitjet dhe vlera e shitjes së agregateve, sigurohen nga operuesit e minierës dhe më pas vlerësohen nga ministritë kompetente (dhe/apo nga autoritetet lokale), të cilat janë të autorizuara të kontrollojnë këto aktivitete në sektorin minerar në çdo vend/rajon të EJL. Raportet statistikore mbi prodhimin historik, konsumin, nevojat dhe trendet e kërkesës dhe ofertës së ardhshme, zakonisht nga ministria kompente në çdo vend (p.sh Ministria e Ekonomisë, Ministria e Mjedisit, Ministria e Minierave dhe Planifikimit të Territorit, Ministria e Transportit) dhe zyrat për statistikat kombëtare.

Për sa i përket të dhënave të prodhuara nga volume e burimeve sekondare dhe përqindja e materialeve të ricikluara, ato kryesisht përllogariten më përafërsi. Për më tepër mungojnë të dhënat mbi përqindjen e porcioneve të ricikluara që po përdoren si agregate, me përjashtim te një ose disa vendeve/rajoneve (Table 2.1).

Duhet theksuar së, në shumicën e vendeve të EJL, burimet sekondare nuk konsiderohen në planifikimn e furnizimit të agregateve. Për pasojë, bazat e të dhënave mbi burimet sekondare ose mungojnë tërësisht ose përmbajnë të dhëna të kufizuara dhe shpesh të pasigurta. Duhet theksuar gjithashtu se përqindja e riciklimit të C\&DW, është ende shumë e ulët në vendet/rajonet e EJL.

Në rajonin e EJL, të dhënat janë të vlefshme në nivel rajonal ose kombëtar bazuar kryesisht në I) në cilin nivel po kryhet planifikimi i agregateve, II) tipin e të dhënave që po mblidhet dhe III) nivelin e autoritetit planifikues.

Në përmbledhja të rezultateve kryesore të anketimit u konkludua se I) inventarët e burimeve agregate nuk janë të zhvilluara njësoj në të gjitha vendet e EJL, II) të dhënat e këtyre inventarëve nuk përiditësohen rregullisht dhe nuk mbahen në formë elektronike, III) të dhënat vijnë nga burime të ndryshme dhe prandaj nuk janë gjithmonë të përputhshme me njëra-tjetrën, IV) informacioni i regjistruar në inventarë nuk kontrollohet dhe shpesh herë ngre dyshime mbi besueshmërinë e tij, V) në shumicën e vendeve/rajoneve të EJL inventarët aktualë nuk përmbajnë data mbi burimet dytësore. 
Tabela 2.1: Vlefshmëria e të dhënave mbi burimet e agregateve dytësore në vendet e EJL (Hatzilazaridou, 2014)

\begin{tabular}{|c|c|c|c|c|c|c|}
\hline \multirow[b]{2}{*}{$\begin{array}{l}\text { Vendi/Rajo } \\
\text { ni }\end{array}$} & \multicolumn{4}{|c|}{$\begin{array}{l}\text { Të dhëna mbi volumet e prodhimit për tup të } \\
\text { mbetjeve të ricikluara (ton) }\end{array}$} & \multirow[b]{2}{*}{$\begin{array}{l}\text { Të dhëna } \\
\text { mbi \% } \\
\text { materiale } \\
\text { ve } \\
\text { dytësore } \\
\text { të } \\
\text { ricikluara }\end{array}$} & \multirow[b]{2}{*}{$\begin{array}{l}\text { Të dhëna } \\
\text { mbi } \% \\
\text { riciklimev } \\
\text { e të } \\
\text { përdorur } \\
\text { a si } \\
\text { agregate }\end{array}$} \\
\hline & $\mathrm{R} 1\left(^{*}\right)$ & $\mathbf{R 2}(*)$ & R3(*) & R4(*) & & \\
\hline Shqipëria & Vlerësuar & JO & JO & Vlerësuar & JO & JO \\
\hline Austria & Vlerësuar & PO & $\mathrm{JO}$ & $\mathrm{PO}$ & $\begin{array}{l}\mathrm{PO}(\mathrm{R} 2) \\
\mathrm{PO}(\mathrm{R} 4)\end{array}$ & $\mathrm{JO}$ \\
\hline Kroatia & Vlerësuar & Vlerësuar & Vlerësuar & Vlerësuar & JO & JO \\
\hline $\begin{array}{l}\text { Emilia Ro- } \\
\text { magna }\end{array}$ & $\mathrm{PO}$ & PO & JO & $\mathrm{PO}$ & PO & JO \\
\hline Greqia & $\mathrm{JO}$ & Estimated & $\mathrm{JO}$ & Vlerësuar & $\mathrm{JO}$ & $\mathrm{JO}$ \\
\hline $\begin{array}{l}\text { Kantonet e } \\
\text { Bosnje } \\
\text { Hercegovin } \\
\text { a }\end{array}$ & JO & JO & JO & JO & JO & JO \\
\hline Hungaria & Vlerësuar & Vlerësuar & JO & Vlerësuar & $\mathrm{PO}$ & JO \\
\hline Mali i Zi & Vlerësuar & JO & JO & Vlerësuar & JO & JO \\
\hline Rumania & Vlerësuar & JO & JO & Vlerësuar & JO & $\mathrm{JO}$ \\
\hline Serbia & Vlerësuar & JO & JO & Vlerësuar & $\begin{array}{l}\text { PO (R1) } \\
\text { JO (R4) }\end{array}$ & $\begin{array}{l}\mathrm{PO}(\mathrm{R} 1) \\
\mathrm{JO}(\mathrm{R} 4)\end{array}$ \\
\hline Sllovakia & Vlerësuar & Vlerësuar & JO & Vlerësuar & $\begin{array}{c}\mathrm{JO}(\mathrm{R} 1) \\
\mathrm{PO}(\mathrm{R} 2) \\
\mathrm{PO}(\mathrm{R} 4)\end{array}$ & JO \\
\hline Sllovenia & Vlerësuar & PO & JO & Vlerësuar & $\begin{array}{l}\mathrm{PO}(\mathrm{R} 1) \\
\mathrm{PO}(\mathrm{R} 2) \\
\mathrm{JO}(\mathrm{R} 4)\end{array}$ & JO \\
\hline Trento & Vlerësuar & PO & Vlerësuar & PO & $\begin{array}{l}\text { JO (R1) } \\
\text { PO (R2) } \\
\text { JO (R3) } \\
\text { PO (R4) }\end{array}$ & PO (R2) \\
\hline
\end{tabular}

$(*)$ Shih figurën 1.2 për shpjegime 


\section{Organizimi i Informacionit}

Planifikimi i agregateve përfshin analiza të proçeseve të ndryshme të ciklit të jetës së materialeve. Këto proçese përkufizohen si "zonat e fokusimit" meqënëse planifikimi duhet ti trajtojë ato në mënyrë individuale dhe kolektive në të njëtën kohë. Këto proçese janë të ndërlidhura me flukset $e$ materialeve, të cilat ndryshojnë në varësi të nivelit të planifikimit. Matrica e informacionit përfaqëson një sistem strukturë hiearkike që ndihmon organizimin e informacionit $q e \ddot{~ n e v o i t e t ~ p e ̈ r ~ p l a n i f i k i m i n ~ e ~ a g r e g a t e v e . ~ N j e ̈ ~ m a t r i c e ̈ ~}$ informacioni duhet të vendoset për çdo nivel planifikimi. 


\subsection{Komponentët e planifikimi}

Planifikimi i agregateve në një mënyrë të qëndrueshme, është çështje e komplikuar.
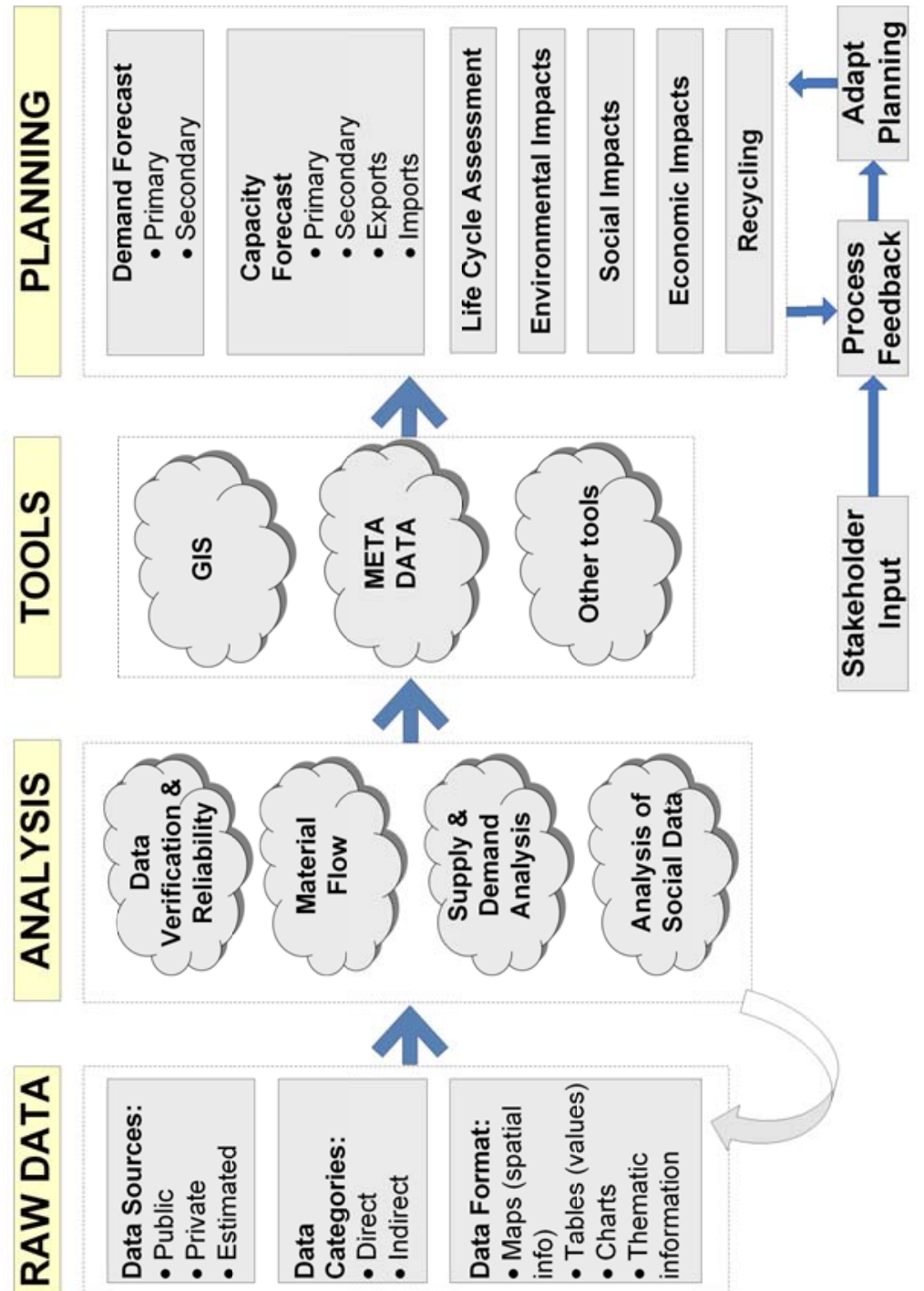

Figura 3.1: Diagramë konceptuale e planifikimit agregat 
Fig 3.1 përfaqëson një diagram konceptuale të asaj që përfshihet në arritjen e një vendimi të marrë në bazë të informacionit. Të dhënat bruto mblidhen nga një larmi burimesh, analizohen në mënyra të ndryshme, kontrollohen, përdoren për llogaritjen e kërkesës, dhe në përfundim implementohen në proçesin e planifikimit. Ky sigurisht është një sistem i komplikuar ndaj dhe ka lidhje të shumta mes proçeseve dhe fazave të tij. Më poshtë po prezantojmë një skemë për të organizuar më mirë fluksin e informacionit duke përdorur konceptin e matricës së informacionit.

\subsection{Ngritja e Matricës së Informacionit}

Qëllimi i këtij manuali është të ndihmojë autoritetet planifikuese në vendet e EJL të ndërtojnë teknika për menaxhimin efektiv të të dhënave të nevojshme për planifikimin e qëndrueshëm të agregateve. Kjo mund të jetë e vështirë për tu arritur për shkak të vështirësisë së përpilimit të një dokumenti të vetëm që do të përshkruajë nevojat e të gjitha vëndeve, për shkak të : I) heterogjenitetit që ekziston mes vendeve të EJL lidhur me menaxhimin e të dhënave; II) mungesa e mjeteve për mbështetjen dhe rregullimin e zhvillimit të agregateve në disa vende; III) kompleksiteti në mekanizmat ekzistues të mbledhjes së të dhënave; IV) mungesa e të dhënave apo informacioneve të sakta si dhe mungesa e metodave për vlerësimin e këtyre të dhënave.

Duke mbajtur në konsideratë situatën e përshkruar më lart, propozohet krijimi dhe ndjekja e disa parimeve bazë, për analizimin e të dhënave për planifikimin e agregateve, të cilat të jenë të kuptueshme për të gjitha autoritet planifikuese të vendeve të EJL.

1. Informacioni i saktë është baza e një planifikimi të sukseshëm;

2. Prodhimi i agregateve, përdorimi dhe riciklimi, përfshijnë një numër aktivitetesh të cilat mund të jenë ose jo të lidhura mes tyre, prandaj planifikimi i qëndrueshëm duhet ti mbajë të gjitha ato aktivitete në konsideratë. Kjo do të thotë që një gamë e gjërë të dhënash duhet të merret nga këto aktivitete;

3. Është e rëndësishme të zhvillohet një strategji dhe nje rutinë për mbledhjen e të dhënave dhe organizimin e tyre;

Përpara fillimit të një proçesi planifikimi në çdo nivel, duhet të identifikohet me saktësi informacioni i nevojshëm.

Një mjet që është krijuar për të ndihmuar organizimin e informacionit në një kuadër llogjik, dhe për të lehtësuar identifikimin e flukseve agregate mes proçeseve të ndryshme (ose zonave të fokusit) si psh prodhimi parësor, riciklimi, etj. Informacioni 
parashikohet në formën e një matrice dhe përfshin të paktën katër kolona dhe numra variabël në rreshta. Çdo rresht përshkruan një proçes, ose fazë të zinxirit, ndërsa kolonat përcaktojnë fushat që karakterizojnë informacionin në çdo rresht. Pas vendosjes së informacionit në matrica në një nivel planifikimi të caktuar, atëhere mbledhja e të dhënave, vleftësimi i tyre, dhe analiza bëhet më e lehtë. Figura 3.2 paraqet një strukturë të thjeshtëzuar informacioni me 7 zona fokusimi dhe 4 kolona informacioni.

Është eveidente se matrica mban në konsideratë të gjithë ciklin e jetes të prodhimit të agregateve dhe siguron një lidhje ndërmjet burimit dhe produktit në një rajon të caktuar. Çdo proçes, ose zonë fokusimi në terma planifikimi, kërkon një grup specifik të dhënash. Zonat e fokusit duhet të ndjekin një vijë llogjike e cila fillon me proçesin e nxjerrjes së mineralit dhe përfundon me shkatërrimin/zhdukjen e materialeve inerte në landfille.

Matrica është e dizenjuar në mënyrë të tillë që të korespondojë me informacionin e cdo proçesi. Çdo proçes mund të ketë më shumë se një aktivitet drejt të njëjtit objektiv, p.sh proçesi i nxjerrjes së mineraleve mund të përfshijë shpërthimin, zgjedhjen e materialeve, etj.

Në kolonën e tabelës jepen lidhjet ndërmjet zonave të fokusit që korespondojnë me rrymën e materialeve; këto lidhje për pasojë mund të përkthehen në tipe të dhënash dhe të dhëna që nevoiten për të kompletuar balancën e materialeve për çdo proçes. Të njëjtat lidhje mund të përdoren si pjesë e vleftësimit të të dhënave.

Përputhja specifike e një produkti me përdorimin e tij specifik, është një parametër $\mathrm{i}$ rëndësishëm që afekton fluksin e materialeve dhe proçesin e ndërlidhjes. Në këtë matricë të thjeshtëzuar të përputhjes së informacionit, nuk parashikohet në mënyrë të shprehur, por mund të përfshihet në kuadrin e të dhënave që korrespondon me çdo zonë fokusi.

Siç u theksua më lart kjo matricë informaciooni duhet të zhvillohet për çdo nivel planifikimi dhe duhet të përshtatet me karakteristikat rajonale. P.sh në një rajon specifik, nxjerrja dhe prodhimi i produkteve përfundimtare, mund të konsiderohet si një zonë fokusimi e vetme, ndërsa në rajone të tjera këto dy proçese mund të konsiderohe të ndara. Rrjedhimisht, në përmbledhje të saj, elementet e mëposhtme duhet të konsiderohen gjatë ndërtimit të Matricës së Informacionit:

$\checkmark \quad$ Cdo zonë fokusimi/proçes duhet të identifikohet nga një objektiv specifik;

$\checkmark \quad$ Të gjithë aktivitetet që kanë qëllim të përbashkët duhet të bashkohen në një proçes të vetëm;

$\checkmark \quad$ Aktivitetet që mund të ndërmerren veç duhet të ndahen në proçese të ndryshme; 
$\checkmark$ Zonat e fokusimit duhet të ndjekin një rend llogjik (nga proçesi i nxjerrjes deri te shkatërrimi).

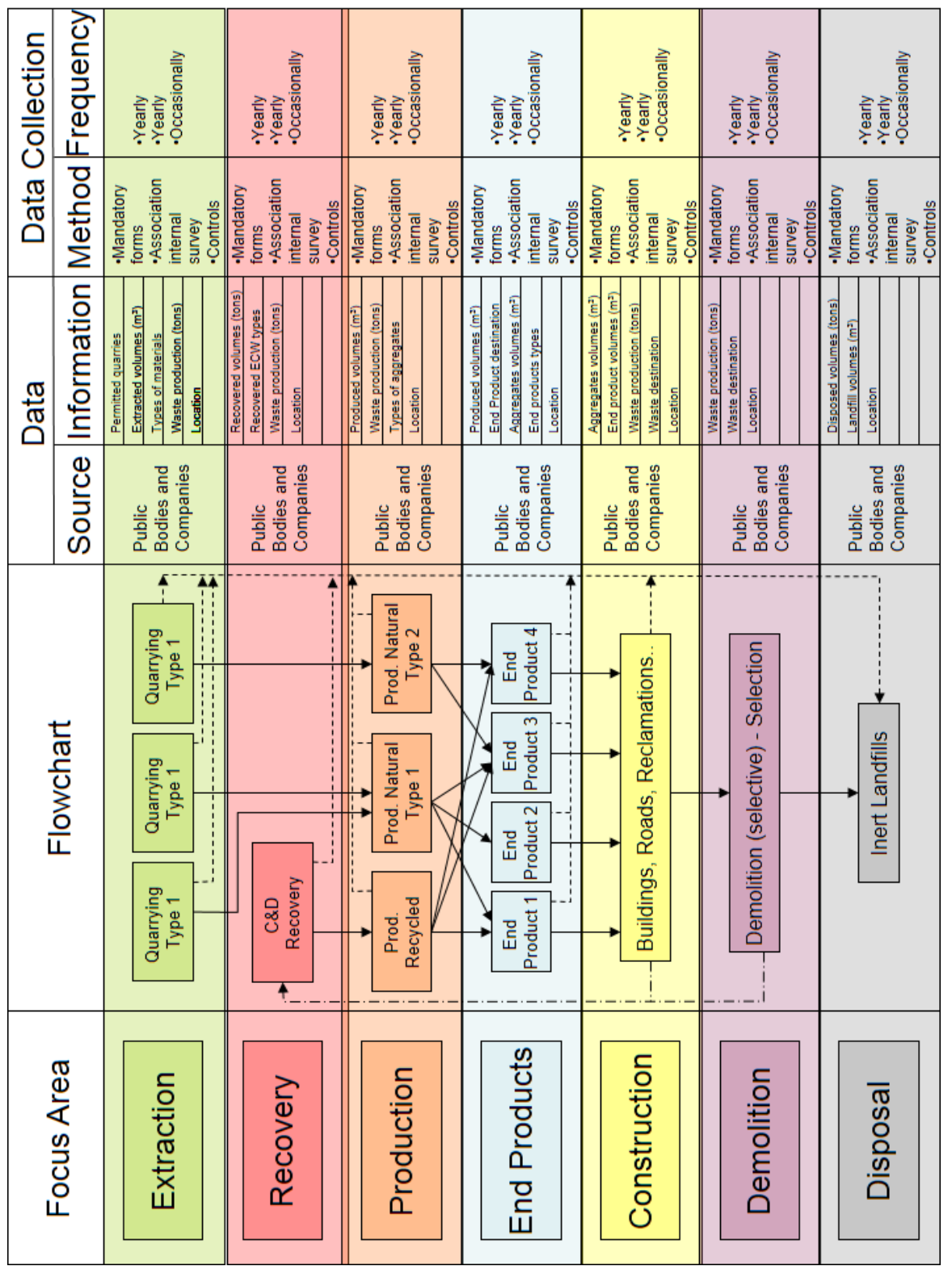

Figura 3.2: Një matricë informacioni e thjeshtëzuar 


\subsection{Kufizimet}

Autoritetet e planifikimit shpesh herë janë qeveri lokale me kufinje gjeografik të mirëpërcaktuar. Këto kufinj, të cilat korrespondojnë me rajonet apo kombet përkatëse, duhet të merren parasysh gjatë analizimit të të dhënave, pavarësisht se do të ishte shumë interesante të aplikohej ky koncept në rajonet fqinje duke i lidhur ato me karakteristikat e përbashkëta gjeografike.

Çdo skeme informacioni ose bazë të dhënash është po aq e mirë sa dhe vetë cilësia e të dhënave që do të menaxhojë. Zhvillimi i një matrice informacioni që nuk mund të implementohet në realitet për shkak të kufizimeve që trashëgon, nuk konsiderohet një praktikë e mirë. Për shembull, disa nga karakteristikat e mëposhtme duhet të mbahen në konsideratë gjatë dizenjimit të matricës së informacionit:

$\checkmark \quad$ Në mënyrë që të sigurohet se të dhënat dhe proçeset përfaqësojnë nivelin e planifikimit, atëhere vetëm të dhënat që i përkasin zonave brenda rajonit duhet të konsiderohen; për më tepër, përveç rastit kur adoptohet një skemë e përbashkët të dhënash, të dhënat e mbledhura në territore të ndryshme brenda të njëjtës ndarje administrative mund të jenë të ndryshme dhe inkosistente;

$\checkmark \quad$ Nëse autoriteti planifikues është i ndryshëm nga instutucioni që mbledh të dhënat, atëhere duhet të harmonizohen nevojat e të dhënave dhe të dhënat që janë mbledhur aktualisht; në të kundërt rezultatet nuk do e ndihmojnë planifikimin.

Gjithëashtu është shume e rëndësishme të kujtohet se i gjithë proçesi ndikohet në shkallë të gjërë nga politikat e vendit dhe nga struktura administrative e shtetit. Rrjedhimisht, në çdo zonë ku aplikohet duhen sqaruar një numër çështjesh përpara implementimit të matricës së informacionit. Për shembull, pyetjet tipikë që duhen zgjidhur janë "cila është politika e shtetit dhe cila është korniza ligjore për mbetjet apo mbetjet e krijuara gjatë proçesit të nxjerrjes" 


\section{Identifikimi i Nevojës për të Dhëna}

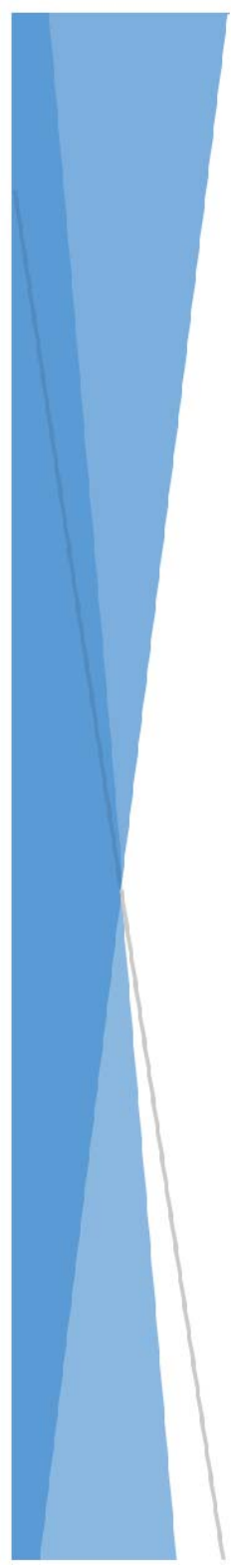

Sigurimi dhe përdorimi $i$ të dhënave të rregullta, të besueshme dhe të përditësuara është tepër i rëndësishëm. Vendosja e proçedurave eficiente për mbledhjen e të dhënave, menaxhimin dhe përpunimin e tyre, është $e$ domosdoshme për zhvillimin e MQBA (Menaxhimin $e$ Qëndrueshëm të Burimeve Agregate) dhe FQM (Furnzimin e Qëndrueshëm Mix). Të dhënat sigurojnë informacion të rëndësishëm, i cili mund të përpunohet dhe bëhet gati për përdorim nga hartuesit e politikave, vendimmarrësit, dhe publiku. Planifikimi i Qëndrueshëm e Agregateve, sikundër shumë disiplina, varet në cilësinë dhe besueshmërinë e të dhënave, por autoritetet planifikuese nuk $i$ kanë gjithmonë resurset dhe mundësinë për ti mbledhur ato. Prandaj ato mbështeten në të dhënat që i sigurojnë agjensitë e tjera. Në cdo raste vendimarrja duhet të mbështetet në burimet më të sigurta dhe shkencërisht të provurara. Të dhënat "perfekte" nuk janë gjithmonë të mundura për tu marrë, por të dhënat cilësore po. Përllogaritjet duhet të përdoren me kujdes gjatë mbledhjes së të dhënave. 


\subsection{Prezantim}

Ky kapitull nxjerr në pah kategoritë kryesore të të dhënave që janë identifikuar, të dhënat e rekomanduara dhe burimet e mundshme të të dhënave. Ky kapitull u përpilua duke mbajtur në konsideratë: 1) informacion nga dokumenta përkatës dokumentacioni i publikuar dhe faqet e internetit, 2) praktikat më të mira të vendeve Europiane, 3) informacion i siguruar nga partnerët e këtij projekti dhe që përmbahen në një pyetësor të aktivitetit 4.1 të projektit lidhur me informacionin dhe të dhënat $\mathrm{e}$ mbledhura në çdo vend/rajon, dhe 4) rezultateve të Projektit MQBA.

\subsection{Formati i të Dhënave}

Të dhënat mund të mblidhen në një nivel kombëtar dhe ose rajonal, në varësi të nivelit ku do të kryehet palnifikimi. Pavarësisht se të dhënat që nevoiten për çdo detyrë mund të jenë të ndryshme, ato mund të kategorizohen si më poshtë:

$\checkmark \quad$ Materiali bibliografik (përfshirë tekstet përshkruese, letrat e bardha, dhe raportet);

$\checkmark$ Tabela statistikore;

$\checkmark$ Harta të shkallave të ndryshme;

$\checkmark$ Informacion tematik, si lidhjet, infrastruktura etj.

Të dhënat mund të vijnë në forma të ndryshme si p.sh:

$\checkmark$ Kopje të shkruara artikujsh, raportesh, dokumenta, tabela, skema, dhe harta të shkallëve të ndryshme;

$\checkmark$ Kopje elektronike të artikujve shkencorë, dokumente, tablea dhe harta të shkallëve të ndryshme;

$\checkmark \quad$ Kopje të shkruara ose elektronike të imazheve satelitore, fotografive nga lart, ose forma të tjera të dhënash vizuale.

Pasi të dhënat për një detyrë specifike janë identifikuar dhe mbledhur, ato duhet të vleftësohen, kombinohen dhe ruhen. Duke qënë se përcaktimi i të dhënave të 'mira' është një proçes që merr shumë kohë, të gjitha këto të dhëna duhet të ruhen dhe të publikohen për të gjitha entitetet nga një burim i vetëm. Pra të dhënat duhet të ruhen në një databazë të përbashkët që të përdoren nga përdoruesit e autorizuar(Fig. 4.1). Baza e të dhënave është një koleksion i rioganizuar i të dhënave që përdoren për te grupuar të gjithë informacionin rreth planifikimit të agregateve, poltikat dhe referenca për burime të tjera. 


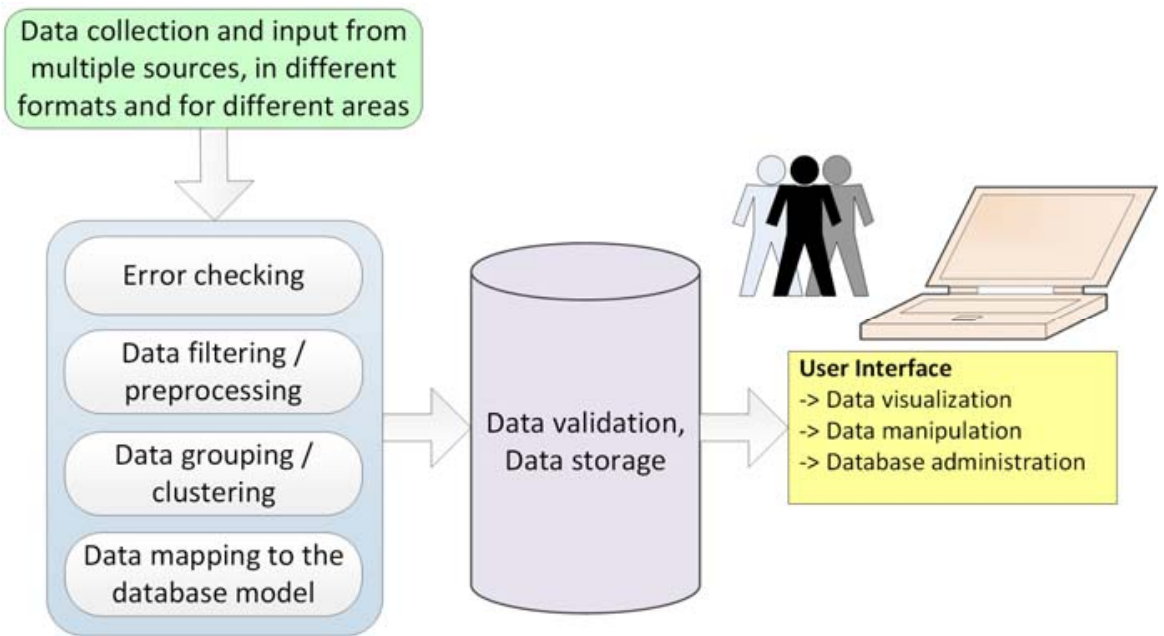

Figura 4.1: Fluksi i të dhënave nga pika e mbledhjes te përdoruesit

Një bazë të dhënash mund të shpërndahet në shumë servera në vendodhje të ndryshme. Është e rëndësishme të sigurohet që baza e të dhënave ka vijimësi dhe përditësohet ose manualisht ose përmes lidhjeve automatike të sistemit qe e monitoron. Ndërtimi i kësaj baze të dhënash mund të jetë një përpjekje e përbashkët e agjensive të ndryshme, si psh byroja e statistikave, ministritë përkatëse, autoritetet rajonale, shërbimi gjeologjik kombëtar, dhe organizata kërkimore.

\subsection{Identifikimi i Grupeve Kryesore të të Dhënave për Agregatet Primare}

Të dhënat që i përkasin agregateve primare duhet të përfshijnë:

$\checkmark \quad$ Të dhëna për ruajtjen e depozitave agregate dhe ose operacioneve;

$\checkmark \quad$ Të dhëna që i përkasin shpërndarjes gjeologjike dhe cilësisë së burimeve;

$\checkmark \quad$ Të dhëna që përshkruajnë rezervat e lejuara, që vlerësojnë shitjet, lejet e reja dhe fondin e tokës(tokave);

$\checkmark$ Të dhëna për shitjen e agregateve, prodhimin/aftësitë prodhuese, konsumimin dhe import/exportet, dhe zakonisht rezultatet e anketimeve;

$\checkmark \quad$ Të dhëna mbi përdorimin e gropave;

$\checkmark \quad$ Të dhëna mbi transportin nga vendi i nxjerrjes së mineraleve në tregjet e konsumimit; 
$\checkmark \quad$ Të dhëna mbi përputhshmërinë e burimeve agregate me specifikimet teknike;

$\checkmark \quad$ Të dhëna mbi kërkesën agregate; kjo do të jetë rezultat i parashikimit të kërkesës përmes metodave të përshtatshme.

Rëndësia e sejcilës prej grupeve të të dhënave përshkruhet më poshtë.

\subsubsection{Të dhëna për ruajtjen e burimeve agregate në planifikimin e përdorimit të tokës}

"Planifikimi i përdorimit të tokës përgjithësisht përmban kritere që determinojnë cfarë lloj zhvillimi mund të marri pjesë në një zonë të veçantë, dhe janë shembuj tipike të planeve model për zhvillimin e ardhshëm" (SEA, 2001). Vendimarrja për alokimin e përdorimit të tokës bazohet në kritere mjedisore; shembujt përfshijnë ruajtjen e natyrës dhe korridore për migrimin e specieve, menaxhimin e bazeneve të lumenjve dhe shmangjen e përmbytjeve, dhe mbrojtjen e dheut dhe ujit.

Vendimet mbi politikën që përcaktojnë përdorimin e tokës janë kryesisht të implementuara përmes planifikimit të hapsirës. Kjo përfshin shkëmbime ndërmjet interesave në sektorë të ndryshëm, përfshirë industrinë, transportin, komunikimin, minierat, agrikulturën, dhe pyjet.

Një sistem efektiv që garanton sigurinë, kërkon adoptimin e "zonave që ruajnë mineralet" dhe përshtatjen e politikave të nevojshme përmes së cilës të menaxhohet zhvillimin në këto zona. Pavarësisht se agregatet primare jane të bollshme nga pikpamja gjeologjike, vlefshmëria e tyre zvogëlohet për shkak të caktimit të tokave për përdorim të ndryshëm. Një politikë e qëndrueshme agregate duhet të ruajrë ekulibrin agregatë në planifikimin e përdorimit të tokës me qëllim që të shmangen konfliktet e mëtejshme. Si në shumë raste, zonat që përmbajnë burime agregate janë në kontradiktë me planifikimin e përdorimit të tokës.

Hartat e ruajtjes së agregateve duhet të përmbajnë informacion mbi rëndësinë identifikimin e bruimeve kombëtare, rajonale dhe lokake, përmes klasifikimit të këtyre burimeve. Planifikimi i përdorimit të tokës duhet të mbështetet nga një strukturë e besueshme të dhënash si më poshtë: 
$\checkmark \quad$ Nje bazë dixhitale njohurish gjeologjike (që përfshin harta gjeologjike 1:50.000. Anketim i mëtejshëm gjeologjik mund të nevoitet në një shkallë nga 1:25.000 në 1:10.000);

$\checkmark \quad$ Një metodologji transparente për identifikimin e burimeve agregate

$\checkmark$ Perllogaritjet afatgjate per kerkesen agregate rajonale dhe lokale duke mbajtur ne konsiderate dhe burime te tjera p.sh (brimet dytesore aggregate)

Të dhënat mund të paraqiten në një shkallë më të ulët (p.sh. 1:100.000) në varësi të detajeve dhe zonës që do të mbulohet. Identifikimi i zonave pa konflikt mund të kryhet përmes një qasje GIS. Ato resusrse që ja vlen të mbrohen për shkak të cilësisë, sasisë dhe mungesës së konfliktit në përdorimin e tokës, duhet ti dorëzohen autoritetit planifikues (kombetar apo rajonal) për ti deklaruar si fond zone për planifikimin e përdorimit të tokës.

Dy shembuj të metodolodjisë së aplikuar se si të prodhohet një harte ruajte agregatesh rekomandohen më poshtë:

$\checkmark \quad$ Plani Austriak i Burimeve Minerare u zgjodh nga një Komisioni ad hoc (2010), i themeluar në kuadrin e Grupit për Furnizimin me Lëndë të Parë, si shembulli i "praktikës më të mirë" të planifikimit kombëtar të përdorimit të tokës për minerale (Austria, 2014);

$\checkmark$ Qasja e përdorur nga Shërbimi Gjeologjik Britanik (BGS, 2012).

\subsubsection{Të dhëna për të përmirësuar bazën e njohurisë për shpërndarjen gjeologjike të burimeve të agregateve primare}

Sasia e agregateve që do të nevoiten në të ardhmen varet nga ekonomia e çdo vendi dhe nevoja për aktivitete ndërtimi, si dhe vlefshmëria e burimeve për investimet e ardhshme në infrastrukturë.

Njohuria për burimet agregate është thelbësore për marrjen e vendimeve efektive dhe të qëndrueshme. Planifikimi i sistemit në menyrë efektive dhe funksionale varet në cilësinë e lartë dhe aksesin në informacion,cilësinë dhe sasinë e burime minerare dhe lidhjen e tyre me planin kombëtar, i cili mund të ketë kufizime për nxjerrjen e mineraleve. Ky informacion është i rëndësishëm për krijimin e një dokumenti kuadër për zhvillimin e mineraleve, si në kontekstin e identifikimit të zonave të ardhme për shfrytëzim mineral, afatgjatë, objektiv dhe duke ruajtur parime të rëndësishme të shfrytëzimit. 
Një objektiv parësor, është të prodhohet një bazë të dhënash në një format konsistent i cili mund të përditësohet, rishikohet, modifikohet që të mbështesi nevojat e planifikimit, dhe përgatitjen e Dokumentave të Planit të Zhvillimit të Mineraleve dhe Strategjitë Rajonale të hapsirës.

Identifikimi i burimeve agregate, kërkon kuptimin e vendndodhjes, shkallës, tipit dhe aksesueshmërisë së burimeve. Qasjet e përdorura për të identifikuar burimet agregate ndryshojnë në nivelin e detajeve dhe shkallës në varësi të nevojave, presioneve dhe vlefshmërisë së agregateve në një zonë. Një qasje e përbashkët është të identifikohen burimet agregate në terma përbërësish gjeologjik dhe shkalle (shkalla e rekomanduar 1:50.000). Hartat e zhvilluara në këtë shkallë mund të përfshijnë informacion lidhur me cilësinë, karakteristikat, dhe zonat me potencial zhvillimi apo shfrytëzimi. Shërbimet Gjeologjike Kombëtare janë zakonisht siguruesit e të dhënave për këtë informacion p.sh cilësia dhe sasisa e burimeve agregate.

Identifikimi i bruimeve strategjike agregate duhet gjithëashtu të trajtojë faktorë kyç që mund të ndikojnë aksesin dhe vlefshmërinë e një burimi agregat në raport me vendndodhjen e tij dhe përdorimin e tokave përreth. Për pasojë është e rëndësishme që autoritetet rajonale/lokale të mbledhin të gjitha nivelet e informacionit në një hartë me shkallë të rekomanduar 1:100.000, duke përdorur edhe mjetet GIS, të cilat duhen përditësuar në mënyrë të rregullt. Katër elemente kryesore informacioni mund të prezantohen në këto harta:

$\checkmark \quad$ Shpërndarja gjeologjike e agregateve dhe vendodhja e vendeve të gërmimit

$\checkmark$ Masa e lejeve për planifikimin mineral

$\checkmark$ Pejsazhet apo vendet natyrore të zgjedhura dhe ruajtja e tyre

Impakti i kufizimeve të përmendura lidhur me aksesin në burimet agregate dhe furnizimin me produkte agregate cilësore duhet të monitorohet në mënyrë periodike, cdo 5 vjet, nga administrata publike në bashkëpunim me grupet e interesit, dhe nësë nevoitet duhet të adoptohen dhe masat përkatëse apo zgjidhje alternative.

\subsubsection{Të dhëna për të aksesuar rezervat e lejuara, shkallën e zvogëlimit, shkallën $e$ zëvëndësimit, dhe fondin e tokave}

Për qëllime planifikimi, fondi i tokës kuotohet i tillë për minerale e agregate. Fondi i tokës është shuma e rezervave të lejuara (aktive apo jo) në një moment të caktuar në një zonë të caktuar. Zakonisht shprehet në terma furnizimi mesatar në vite. Zona 
nën konsiderim zakonisht korrespondon me një Autoritet Planifikimi Mineral (APM) ose grup APM's. Fondi i tokës siguron një indikator të shkallës së nevojës për miratimin e lejeve të reja. Gjatësia minimale e fondit të tokës reflekton nevojën që nevoitet për të marrë një leje planifikimi dhe të fillosh prodhimin e rregullt. Duke qënë se ky proçes mund të marrë disa vite, rekomandohet që fondet e tokës të garantojnë rezerva të mjaftueshme për të paktën 20 vite.

Autoritetet planifikuese duhet të sigurojnë një fond toke për rezervat agregate. Kur kufinjtë e tregjeve agregate shtrihen përtej kufinjve të autoriteteve lokale, këto të fundit duhet të punojnë bashkë për të siguruar ofrimin e një oferte të përshtatshme minerale. Kjo është veçanërisht e rendësihme në rajonet me qytete.

Është e rëndësishme që grupet e interesit, përfshirë industrinë agregate, të angazhohen në planifikimin e fondit të tokës. Nuk duhen lejuar konsente të reja nëse vendndodhja, në terma planifikimi, është e pa përshtatshme për krijimin e një fondi toke. Nevoja për identifikimin e zonave të kërkimit mund të shmanget nga të dhëna të sakta mbi fondin e tokave, prandaj duhet të shihet në frymën e zhvillimit të skemës së planifikimit. Shkalla e fondit të tokës duhet të përcaktohet në planin lokal të zhvillimit.

\subsubsection{Të dhëna mbi shtijen e agregateve, prodhimin/aftësinë prodhuese, konsumin dhe import/exportet}

Këto anketime (të kryera në interval 4 vjecare) duhet të sigurojnë informacion të thellë dhe të përditësuar mbi shitjet në nivel lokal dhe kombëtar, flukset ndërrajonale, transportin, konsumin, prodhimin dhe rezervat e lejuara të agregateve primare. Këto të dhëna zakonisht sigurohen nga burimet zyrtare (autoritetet planifikuese) dhe kompanitë që operojnë në këtë fushë dhe duhen përditësuar rregullisht. Njësia e matjes është në ton. Duhen përcaktuar dhe vlerat për shitjet nga import-exportet. Anketimet duhet të përdoren, për të informuar autoritetet mbi prodhimin, transportin dhe konsumin e agregateve primare, transportin dhe konsumin agregateve në mënyrë që të monitorohet dhe rishikohen manuali $i$ agregateve, të monitorohen politikat e zhvillimit për menaxhimin e ofertës agregate në çdo vend/rajon.

\subsubsection{Direktoria e zonave agregate aktive dhe in-aktive}

Baza e të dhënave të zonave agregate aktive dhe inaktive duhet të përmbajë këtë informacion:

$\checkmark \quad$ Statusi (aktiv ose inaktiv); 
$\checkmark$ Emri;

$\checkmark \quad$ Koordinatat e vendndodhjes gjeografike;

$\checkmark$ Adresa;

$\checkmark$ Operatori;

$\checkmark \quad$ Gjeologjia (bazuar në shkallën 1:50.000);

$\checkmark \quad$ Shifrat e prodhimit në ton;

$\checkmark \quad$ Aftësia e prodhimit në ton;

$\checkmark \quad$ Përodrusi i fundit i produktit nësë njihet;

$\checkmark \quad$ Sasia e shitjeve në ton;

$\checkmark \quad$ Data e skadimit të lejes;

$\checkmark$ Rezerva totale e burimit;

$\checkmark \quad$ Pjesa e mbetur e rezervës së burimit;

$\checkmark \quad$ Shifrat e prodhimit për 3 vitet e shkuara (e aplikueshme dhe në statusin e përkohshëm inaktiv).

Baza e të dhënave dhe GIS i asocuar do të sigurojnë një mjet të vlefshëm për monitorimin e kapacitetit të prodhimit, rezervave dhe mbarimin e burimit.

\subsubsection{Të dhënat mbi gropat e përkohshme}

Zona të vogla pune, të quajtura herë pas here gropa të përkohshme, të cilat shpesh herë lidhen me ndërtimin e rrugëve, pyjtarinë dhe agrikulturën, dhe që lejojnë nxjerrjen e mineraleve pranë zonës së zhvillimit. Këto zona të vogla pune do të kërkojnë leje normale zhvillimi punimesh, e cila jepet brenda qëllimit të zhvillimit. Vlefshmëria e agregateve primare, mund ta tejkalojë nevojën për punime të tilla, në mënyrë që aplikantët ta provojnë përftimet komunitare apo ambjentaliste të propozimeve të tyre. Gjithëashtu duhet të ketë kufizime kohe për çdo projekt propozim (SPP, 2006).

\subsubsection{Të dhëna për të vlerësuar impaktin e transportit të agregateve nga vendi ku nxirren drejt tregjeve të konsumit.}

Një Vlerësim Transporti në mbështetje të një aplikimi, duhet të ndihmojë autoritet e planifikimit për të vlerësuar impaktin e transportit në zhvillim. Agregatet e përdorura në ndërtim, nuk transportohen më shumë se $50 \mathrm{KM}$ me rrugë, osë ndryshe do të kenë defiçensa ekonomike, pavarësisht se mineralet me vlerë të lartë shërbejnë në tregje të largëta. Kur transporti ka impakt domethënës në komunitetin lokal, duhet ti jepet vëmëndje e lartë rrugëve nga do të kalojë ky transport. Kur mundësia e transportit përmes hekurudhës, apo transportit ajror nuk janë alternative 
përkundrejt trasnportit rrugor, aksesi në zonën e nxjerrjes së mineraleve mbetet një cështje për tu trajtuar.

Kur është e mundur zonat e reja të gërmimit, duhet të orientohen pranë zonave të mëdha urbane të cilat janë dhe tregjet kryesore, në mënyrë që të shkurtohen distancat e transportit, trafiku, konsumi i energjive, dhe ndotja mjedisore.

\subsubsection{Të dhëna mbi përpuethshmërin e burimeve agregate me specifikimet teknike}

Të gjitha agregatet (primare dhe sekondare) duhet të kenë disa standarte minimale për tu përdorur në industrinë e ndërtimit. Ato duhet ti nënshtrohen çertifikimeve përkatëse, dhe duhet të përputhen me të gjitha standartet kombëtare apo të BE. Për tu siguruar se agregatet vazhdimisht i plotësojnë kërkesat e tregut dhe të përdorimit, duhet të ndërmerren një seri testesh laboratorike. Një listë e plotë e testeve të përcaktuara nga BE për të vlerësuar standartet, po i japim më poshtë. Dokumenti standart që do të dali, duhet të konsultohet me të gjitha detajet e testeve dhe metodat e përdorura për këtë qëllim.

EN 932 Teste për karakteristikat e përgjithshme të agregateve

EN 933 Teste te përgjithshme gjeomtrike të agregateve

EN 1097 Teste për karakteristikat mekanike dhe fizike të agregteve

EN 1367 Teste për karakteristikat termale të agregateve

EN 1744 Teste për karakteristikat kimike të agregateve

Gjithëashtu ka dhe standarte Europiane të cilat specifikojnë vlerat e pranushme për çdo test. Agregatet duhet të bien brenda limiteve të testeve në mënyrë që të konsiderohen të përshtatshme për përdorim. Standartet e nevojshme janë si më poshtë:

EN 12620 Agregate për beton

EN 13043 Agregate për përzierje bitumi dhe rrugë automobilistike me trafik

EN 13055 Agregate me peshë të lehtë

EN 13139 Agregate për llaç

EN 13242 Agregate për material hidraulike

EN 13383 Gur armature

EN 13450 Çakëll hekurudhe

\subsubsection{Të dhëna për të mbështetur parashikimin e kërkesës}

Kërkesa agregate udhëhiqet nga aktivikiteti në industrinë e agregateve dhe ekonominë në përgijthsi. Sipas UEPG (2013) rreth 30 kt agregate nevoiten një km rrugë të re. Për pasojë parashikimi i kërkesës luan një rol të rëndësishëm në formulimin e politikës kombëtare dhe rajonale, dhe në përcaktimin e ofertës në terma afatgjatë. Nëse një qeveri lokale apo kombëtare mund të përllogarisi kërkesën 
agregate "mund të formulojë një politikë agregate të saktë" dhe të llogarisi cili proporcion i kërkesës mund të kenaqi kërkesat për furnizim. Metoda të ndryshme parashikimi mund të aplikohen bazuar edhe në trendet historike me qëllim që të bëhen parashikime të sofistikuara ekonomike. (shih kapitullin 5).

\subsection{Identifikimi i kuadrit kryesor të të dhënave për Agregatet Kryesore}

Tipe të ndryshme të nënprodukteve të mbetjeve minerale mund të kthehen në produkte sekondare përmes riciklimit. Këto produkte mund të përdoren për të zëvëndësuar ato që mungojnë ose duke $u$ miksuar me agregatet natyrale për përdorime të ndryshme, duke kursyer në këtë mënyrë burime të pariciklueshme dhe duke ruajtuar tokën e mjedisin. Burimet e agregateve sekonadre kanë një karakter të fortë rajonal (Blengini et al, 2013).

Katër tipe të aktivitetit riciklues konsiderohen si burime të mundshme të burimeve agregate dhe ilustrohen në tabeën 4.1. Të dhënat që u përkasin agregateve sekondare duhet të përfshijnë:

$\checkmark \quad$ Të dhëna për specifikime teknike;

$\checkmark \quad$ Të dhëna për impaktin mjedisor;

$\checkmark \quad$ Volumin dhe përqindjen për tip të burimeve sekondare të përdorura;

$\checkmark \quad$ Volumin dhe përqindjen për tip të bruimeve sekondare të ricikluara;

$\checkmark \quad$ Volumin dhe përqindjen të materialit të ricikluar të përdorur si zëvëndësues për agregatet primare.

\subsubsection{Të dhëna mbi specifikimet teknike}

Të njëjtat standarte Europian që aplikohen te agregatet primare (shih seksionin 4.3.8) aplikohen gjithashtu dhe te burimet agregate sekondar. Standartet bazohen në përpuethshmërinë dhe qëllimin e agregateve se sa në burimin e tyre.

\subsubsection{Të dhëna mbi impaktin mjedisor}

Aktivitetet e përpunimit të burimeve agregate sekondare, zjgerimi në vendodhje dhe ndryshimi i përdorimit të vendndodhjeve egzistente kërkon leje mjedisore dhe planifikimi. Përpunimi i tyre prodhon pluhur, zhurmë, dhe ndot tokën dhe ujin nëse transporti i prodkteve nuk menaxhohet drejtë ( $p . s h$ emetimet e karbonit dhe zhurma). Përpara se të fillojë përpunimi, ato ende klasifikohen si mbetje; për pasojë 
Tabela 4.1: Klasifikimi i aktiviteteve të riciklueshme si burim potencial i prodhimit të agregateve dytësore (Chalkiopoulou\& Hatzilazaridou, 2011)

\begin{tabular}{|l|l|}
\hline R1: & $\begin{array}{l}\text { Riciklimi i nënprodukteve, dhe mbetjeve nga aktivitetet e nxjerrjes së } \\
\text { mineraleve }\end{array}$ \\
\hline R2: & Riciklimi i mbetjeve të ndërtimit dhe shkatërrimit (C\&DW) \\
\hline R3: & Riciklimi i gurëve apo dheut nga veprat publike \\
\hline R4: & Riciklimi i mbetjeve industrial \\
\end{tabular}

ato duhet të trajtohen bazuar në rregulloret e menaxhimit të mbetjeve sipas çdo vendi (SA, 2014).

\subsubsection{Të dhëna mbi volume e burime sekondare}

Vetëm një porcion i burimeve sekondare mund të jetë i përshtatshëm për përdorim agregat. Për planifikim të qëndrueshëm dhe efektiv të agregateve, është e rëndësishme të mblidhet informacion jo vetëm mbi porcionet e përdorura por dhe mbi përqindjen e agregateve primare të përdorura gjatë FQM.

Nxjerrja e inerteve ose mbetjeve minerare (R1) mund të bëhet, pas trajtimit, një burim i mundshëm agregat. Meqënëse mbetjet inerte mund të bëhen burime agregate, përpilimi i listave të mbetjeve inerte, mund të nxisi zhvillimin e një skeme të integruar të menaxhimit të mbetjeve. Gjithëashtu, bazuar në kriterin (d) Vendimi i Komisionit 2009/359, mbetjet minerare konsiderohen mbetje inerte vetëm nëse përmbajnë mbetje të vogla të metaleve të rënda dhe nuk tejkalojnë "pragun kombëtar për vlerat e karakterizuara si të pa kontaminuara ose nivelet përkatëse kombëtare".

Mbetjet e Ndërtimit \& Shkatërrimit (R2) gjenerohen gjatë ndërtimit të infrastrukturës publike dhe aktiviteteve të ndërtimit dhe shkatërrimit të ndërtesave, riparimit të rrugëve etj. Identifikimi i këtyre mbetjeve është konsideruar si një prioritet nga Komisioni Europian, meqënëse përbën një nga linjat më të mëdha të mbetjeve, e cila përfaqëson 50 \% të mbetjeve totale në Bashkimin Europian (BE). Aktulisht ky tip mbetje mbulohet nga Direktiva 2008/98/EC mbi mbetjet (e cila shfuqizojë direktivën 2006/12/EC). Riciklimi i C\&DW arrihet përmes faciliteteve të riciklimit (fikse apo të lëvizshme).

Mbetjet e gërmimit (R3) të gjeneruar nga veprat përdoren shpesh herë në vend të agregateve primare. Megijthatë, kjo, konkuron drejtpërdrejtë (shpesh jo në mënyrë të ndershme) operacionet e lejuara agregate, meqënëse prodhimi i tyre nuk është objekt 
pagesash apo rente minerare. Origjina e kësaj mbetje duhet të investigohet me kujdes përpara se të lejohet furnizimi mix.

Mbetja industriale (R4) mund ta ketë origjinën nga proçese të ndryshme industriale. Skorja/Shllag është një mbetje industriale e cila përdoret për prodhimin e çimentos dhe agregateve gjithashtu.

Përllogaritja e përqindjes së C\&DW që riciklohet, zakonisht bazohet në sasinë e ricikluar nga entiteti që e kryen. Gjithëashtu përllogaritja e përqindjes së ricikluar të C\&DW e cila përdoret si agregat, bazohet në sasitë që janë shitur.

\subsection{Shembuj të formatit të të dhënave për mbledhjen e tyre}

Në këtë seksoin paraqiten një numër tabelash apo formatesh për mbledhjen e të dhënave. Formatet duhet të ndërtohen për të trajtuar si informacionin mbi një set të caktuar të dhënash, ashtu dhe në një zonë të caktuar fokusimi si psh në Kapitullin 3.

\section{Burimet Gjeografike}

\begin{tabular}{|l|l|l|l|l|l|l|}
\hline $\begin{array}{l}\text { Rrethi } \\
\text { Administrativ } \\
\text { i Planifikimit } \\
\text { (p.sh., Rajoni, } \\
\text { Shteti) }\end{array}$ & $\begin{array}{l}\text { Koordin } \\
\text { atat e } \\
\text { vendodh }\end{array}$ & $\begin{array}{l}\text { Tipi i } \\
\text { formacion } \\
\text { it }\end{array}$ & $\begin{array}{l}\text { Shkalla } \\
\text { e } \\
\text { hartës }\end{array}$ & Rezervat & $\begin{array}{l}\text { Përllogaritja e } \\
\text { Cllësive } \\
\text { Teknike/ } \\
\text { Karakteristika } \\
\text { t }\end{array}$ & $\begin{array}{l}\text { Agjensia } \\
\text { përgjegjë } \\
\text { se }\end{array}$ \\
\hline $\begin{array}{l}\text { p.sh Zona e } \\
\text { Bruimit }\end{array}$ & & & & & & \\
\hline
\end{tabular}

\section{Rezervat Gjeologjike}

\begin{tabular}{|c|c|c|c|c|c|}
\hline $\begin{array}{l}\text { Rrethi } \\
\text { Administrativ i } \\
\text { Planifikimit (p.sh., } \\
\text { Rajoni, Shteti) }\end{array}$ & $\begin{array}{l}\text { Koordi } \\
\text { natat } \\
\text { e } \\
\text { vendo } \\
\text { dhjes }\end{array}$ & $\begin{array}{l}\text { Tipi i } \\
\text { formacionit }\end{array}$ & $\begin{array}{l}\text { Shkalla e } \\
\text { hartës }\end{array}$ & Rezervat & $\begin{array}{l}\text { Përllogaritja e } \\
\text { Cllësive } \\
\text { Teknike/ } \\
\text { Karakteristika }\end{array}$ \\
\hline p.sh Zona e Bruimit & & & & & \\
\hline
\end{tabular}

\section{Rezervat e Lejuara}

\begin{tabular}{|c|c|c|c|c|c|c|}
\hline $\begin{array}{l}\text { Rrethi } \\
\text { Administrativ i } \\
\text { Planifikimit (p.sh., } \\
\text { Rajoni, Shteti) }\end{array}$ & $\begin{array}{l}\text { Koordinat } \\
\text { at e } \\
\text { vendodhj } \\
\text { es }\end{array}$ & $\begin{array}{l}\text { Tipi i } \\
\text { formacion } \\
\text { it }\end{array}$ & $\begin{array}{l}\text { Shkall } \\
\text { a e } \\
\text { hartës }\end{array}$ & Rezervat & $\begin{array}{l}\text { Përllogarit } \\
\text { ja e } \\
\text { Cllësive } \\
\text { Teknike/ } \\
\text { Karakteris } \\
\text { tika }\end{array}$ & $\begin{array}{l}\text { Mbajt } \\
\text { ësi i } \\
\text { lejes }\end{array}$ \\
\hline $\begin{array}{l}\text { p.sh Zona e } \\
\text { Bruimit }\end{array}$ & & & & & & \\
\hline
\end{tabular}




\section{Agregatet Primare}

\begin{tabular}{|l|l|l|l|l|l|}
\hline $\begin{array}{l}\text { Informacion } \\
\text { mbi zonën e } \\
\text { gërmimit } \\
\text { (Aktive \& } \\
\text { Inac=tive) }\end{array}$ & $\begin{array}{l}\text { Vendodhja e } \\
\text { zonës së } \\
\text { gërmimit } \\
\text { (koordinatat) }\end{array}$ & $\begin{array}{l}\text { Viti i } \\
\text { fillimit } \\
\text { të lejes }\end{array}$ & $\begin{array}{l}\text { Viti i } \\
\text { mbarimit } \\
\text { të lejes }\end{array}$ & $\begin{array}{l}\text { Tipi i } \\
\text { formacioneve } \\
\text { të gurëve }\end{array}$ & $\begin{array}{l}\text { Karakteristikat } \\
\text { teknike (\#) }\end{array}$ \\
\hline 1. & & & & $\begin{array}{l}\text { p.sh., gur } \\
\text { gëlqeror, gur } \\
\text { vullkanik, etj. }\end{array}$ & $\begin{array}{l}\text { p.sh ., përbërje } \\
\text { kimike. }\end{array}$ \\
\hline
\end{tabular}

(\#)për aplikim të rekomanduar

\section{Minierë aktive për Agregatet Primare}

\begin{tabular}{|l|l|l|l|l|l|}
\hline $\begin{array}{l}\text { Qëndra e } \\
\text { podhimit } \\
\left({ }^{*}\right)\end{array}$ & $\begin{array}{l}\text { Lista e } \\
\text { Minierave } \\
\text { Aktive }\end{array}$ & $\begin{array}{l}\text { Viti i } \\
\text { Raportimit }\end{array}$ & $\begin{array}{l}\text { Prodhimi } \\
\text { vejtor në ton } \\
(* *)\end{array}$ & $\begin{array}{l}\text { Kapaciteti } \\
\text { aktual në } \\
\text { ton }\end{array}$ & $\begin{array}{l}\text { Rezervat e } \\
\text { mbetura në ton }\end{array}$ \\
\hline 1 & 1.1 & & & & \\
\cline { 2 - 6 } & 1.2 & & & & \\
\cline { 2 - 6 } & $1 . n$ & & & & \\
\hline 2 & 2.1 & & & & \\
\hline & $2 . n$ & & & & \\
\hline
\end{tabular}

$\left(^{*}\right)$ Varet nga niveli i planifikimit, p.sh në nivel Rajonal, Lokal, Bashkiak etj

$(* *)$ për madhësine e prodhuar

\section{Minierat inaktive për Agregatet Primare}

\begin{tabular}{|l|l|l|l|l|}
\hline $\begin{array}{l}\text { Qëndra e } \\
\text { prodhimit }\left(^{*}\right)\end{array}$ & $\begin{array}{l}\text { Numri i } \\
\text { minierave } \\
\text { inaktive }\end{array}$ & Viti i raportimit & $\begin{array}{l}\text { Kapacitetet } \\
\text { Aktuale në ton }\end{array}$ & $\begin{array}{l}\text { Rezervat e } \\
\text { mbetura në ton }\end{array}$ \\
\hline & & & & \\
\hline
\end{tabular}

$\left({ }^{*}\right)$ Varet nga niveli i planifikimit, p.sh në nivel Rajonal, Lokal, Bashkiak etj

\section{Planifikimi i përdorimit të tokës}

\begin{tabular}{|l|l|l|}
\hline Identifikimi i zonës së gërrmimit & $\begin{array}{l}\text { Koordinatat e } \\
\text { vendodhjes }\end{array}$ & $\begin{array}{l}\text { Identifiko agjensinë } \\
\text { përgjegjëse }\end{array}$ \\
\hline $\begin{array}{l}\text { Zona nuk lejohet nxjerrja e } \\
\text { mineraleve }\end{array}$ & & Qeverisje Lokale-qëndrore \\
\hline $\begin{array}{l}\text { Zona ku nxjerrja lejeohet duke } \\
\text { plotësuar disa kushte }\end{array}$ & & \\
\hline Nxjerrja minerale lejohet & & \\
\hline Burimet janë të ruajtura & & \\
\hline
\end{tabular}


Impakti mjedisor si rezultat i planifikimit të propozuar agregat

\begin{tabular}{|l|l|l|}
\hline $\begin{array}{l}\text { Monitorimi i cilësisë së ajrit pranë } \\
\text { njësive të punës }\end{array}$ & \\
\hline $\begin{array}{l}\text { Monitorimi i cilësisë së ujit pranë } \\
\text { njësive të punës }\end{array}$ & & \\
\hline Kufizime të tjera mjedisore & & \\
\hline & & \\
\hline
\end{tabular}

Prodhimi sekondar për mbetjet Minerare/Nënproduktet/Mbetjet nga gërmimet (R1)

\begin{tabular}{|l|l|l|l|l|l|}
\hline $\begin{array}{l}\text { Facilitete të } \\
\text { Agregateve } \\
\text { Sekondare } \\
\text { (Minierë, } \\
\text { gurore) }\end{array}$ & $\begin{array}{l}\text { Vendodhja } \\
\text { (Koordinatat) }\end{array}$ & $\begin{array}{l}\text { Viti i } \\
\text { fillimit të } \\
\text { lejes }\end{array}$ & $\begin{array}{l}\text { Viti i } \\
\text { përfundimit } \\
\text { të lejes }\end{array}$ & $\begin{array}{l}\text { Tipet e } \\
\text { produkteve }\end{array}$ & $\begin{array}{l}\text { Karakteristikat } \\
\text { teknike (\#) }\end{array}$ \\
\hline 1. & & & & & $\begin{array}{l}\text { p.sh } \\
\text { karakteristikat } \\
\text { kimike, të } \\
\text { përbërjes etj }\end{array}$ \\
\hline
\end{tabular}

(\#) Për aplikim të rekomanduar

Prodhimi i agregateve sekondare për C\&DW (R2\&R3)

\begin{tabular}{|l|l|l|l|l|l|}
\hline $\begin{array}{l}\text { Facilitetet e } \\
\text { Përpunimit } \\
\text { të } \\
\text { Agregateve } \\
\text { Sekondare }\end{array}$ & $\begin{array}{l}\text { Vendodhja } \\
\text { (Koordinatat) }\end{array}$ & $\begin{array}{l}\text { Viti i } \\
\text { fillimit të } \\
\text { lejes }\end{array}$ & $\begin{array}{l}\text { Viti i } \\
\text { përfundimit } \\
\text { të lejes }\end{array}$ & $\begin{array}{l}\text { Tipet e } \\
\text { produkteve }\end{array}$ & $\begin{array}{l}\text { Karakteristikat } \\
\text { teknike (\#) }\end{array}$ \\
\hline 1. & & & & & $\begin{array}{l}\text { e p.sh } \\
\text { karakteristikat } \\
\text { kimike, të } \\
\text { përbërjes etj }\end{array}$ \\
\hline
\end{tabular}

(\#)Për aplikim të rekomanduar

Facilitetet aktive për prodhimin e Agregateve Sekondare

\begin{tabular}{|l|l|l|l|l|l|}
\hline Faciliteti $\left(^{*}\right)$ & $\begin{array}{l}\text { Lista e } \\
\text { faciliteteve } \\
\text { aktive }\end{array}$ & $\begin{array}{l}\text { VIti i } \\
\text { raportimit }\end{array}$ & $\begin{array}{l}\text { Prodhimi } \\
\text { kombëtar në } \\
\text { ton }\left({ }^{* *}\right)\end{array}$ & $\begin{array}{l}\text { Kapaciteti } \\
\text { aktual në } \\
\text { ton }\end{array}$ & \\
\hline 1 & 1 & & & & \\
\hline & & & & & \\
\hline & & & & & \\
\hline
\end{tabular}

$\left({ }^{*}\right)$ Varet nga niveli i planifikimit, p.sh në nivel Rajonal, Lokal, Bashkiak etj 


\section{Metoda Analitike}

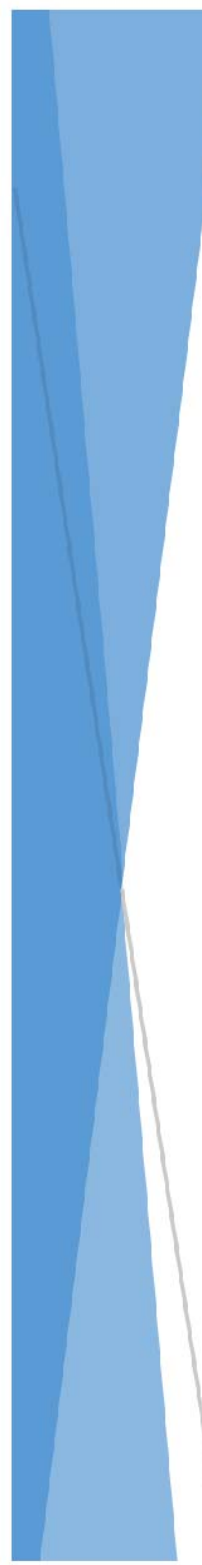

Informacioni i aktualizuar është më mirë së përllgoaritja e të dhënave; informacioni i besueshëm është baza për një skemë të sukseshme planifikimi. Marrja e informacionit të besuaeshëm është përpjekja kryesore. Në të njëjtën kohë, vleftësimi i të dhënave është një hap i rëndësishëm për të siguruar saktësinë e informacionit të mbledhur. Parashikimi i kërkesës, pjesa më e rëndësishme $e$ aktivitetit të planifikimit, duhet të bazohet në të dhëna të sigurta. Ky parashikimi mund të kryhet përmes një varieteti formash, në varësi të të dhënave që janë në dispozizion, dhe duhet rishikuar rregullisht për të reflektuar ndrvshimet e kushteve ekonomike. 


\subsection{Prezantim}

Mbledhja dhe ruajtja e të dhënave, është një përpjekje që ndërmerret sepse informacioni është nevoja bazë për të mbështetur menaxhimin e agregateve dhe politikën e planifikimit. Analizimi $i$ të dhënave mund të ndahet në tre kategori: kontrolli i cilësisë, interpretimi, dhe parashikimi. Kontrolli i cilësisë është i rëndësishëm sepse shmang gabimet apo pasaktësitë në proçesin e mbledhjes së të dhënave. Për më tepër, ndonjëherë është e nevojshme të përdoren shifra të përafërta, pavarësisht se informacioni i saktë është më i preferuar. Rrjedhimisht, kontrolli i cilësisë është një hap i rëndësishëm për të garantuar sigurinë dhe saktësinë e të dhënave.

Në shumë raste, informacioni merret dhe nga të dhëna të pa-përpunuara. Megjithëatë, duke mbajtur parasysh tregun e të dhënave, edhe kjo formë mund të jetë e dobishme. Njëra qasje është të analizosh fluksin e material përmes sektorit agregat. Kjo mund të konsiderohet si pjesë e proçesit të vleftësimit të të dhënave, por gjithëashtu rrit kuptueshmërinë si ti utilizosh burimet me më shumë efikasitet. Pra të dhënat mund të analizohen në formë të thjeshtë apo të komplikuar për të kutpuar më mire kushtet e ardhshme apo të shkuara. Një nga kategoritë më të rëndësishme të modeleve të parashikuara që përdoret gjatë planifikimit është ajo e parashikimit të kërkesës, e cila ka rëndësinë kryesore në proçesin e vendimarrjes.

\subsection{Vleftësimi i të dhënave}

Sikundër shpjeguar më parë, në mënyrë që të zvogëlohet hapsira ndërmjet prodhimit dhe kërkesës p.sh sasia që pritet të futet në përdorim, është e rëndësishme që informacioni dhe të dhënat që do përdoren për fazën e planifikimit të jenë të bësueshme dhe të pasqyrojnë territorin ku janë marrë. Për këtë qëllim një analizë për vleftësimin e të dhënave duhet të kryhet në mënyrë që të konfirmohet nëse cilësia e tyre është e kënaqshme.

Këtu e në vijim, disa pika fillimi për vleftësimin e të dhënave do të ilustrohen me referencë skemën e figurës 3.2. Në thelb, proçesi i vleftësimit mund të arrihet horizontalisht apo vertikalisht, në varësi të objektivit të vleftësimit të të dhënave, por edhe në varësi të përdorimit final të informacionit.

Vleftësimi horizontal konsiston në kontrollin e të dhënave nga pyetësorët, planet, projektet ose statistikat nga të cilat të dhënat janë mbledhur apo orgaznizuar. 
Përmirësimi dhe përditësimi i vazhdueshëm i tyre janë element thelbësor në rritjen e besueshmërinë dhe saktësisë së të dhënave.

Kryerja e vleftësimit të të dhënave në formë vertikale, do të thotë verifikimi i besueshmërisë, dhe nëse është e nevojshme dhe korigjimi i gabimeve të mundshme. Ky është dhe një hap i rëndësishëm në ciklin e jetës të të dhënave, sepse ndikon në besueshmërinë e rezultateve përfundimtare të analizës. Në këtë kuptim, është e rëndësishme të vendosen disa Objektiva mbi Cilësinë e të Dhënave (OCD), të cilat përcaktojnë karakteristikat e dëshiruara të të dhënave në çdo sektor ku do të mblidhen të dhënat (afatet kohore, zona gjeografike, preçisioni, burimi etj). Disa nga indikatorët e OCD've mund të përdoren për të përcaktuar cilësinë e të dhënave që janë në dispozicion, por dhe pragun e vlerësimit të tyre.

Duke iu referuar skemës në Flgurën 3.2, vleftësimi horizontal i të dhënave lidhet me informacionin e një zone fokusimi (ose njësive të veçanta), si p.sh faza e nxjerrjes minerare ose rikuperimi i mbetjeve nga C\&D (ndërtimi dhe shkatërrimi).

Në përgjithësi, procesi i vleftësimit të të dhënave, përfshin tre komponentë kryesorë: redaktimi i të dhënave (identifikimi i të dhënave të pasakta), menaxhimi i të dhënave që mungojnë (rregullimi i të dhënave që mungojnë), dhe vleftësimi $i$ avancuar $i$ të dhënave (përmirësimi i cilësisë së të dhënave duke përdorur metoda statistikore).

Verifikimi i vleftësimit lidhet me fluksin e hyrje/daljeve nga dhe brenda një njësie specifike të proçesit. Në këtë mënyrë do të jetë e mundur të kontrollohen të dhënat që përfshihen apo nxirren nga një proçes dhe do të mund të identifikohen humbjet nga sistemi i të dhënave. Më konkretisht kjo tip analize është e bazuar në balancat apo fluksin e të dhënave që kalojnë nga një njësi e proçesit te një tjetër (Figura 5.1). Ky ekuacion mban në konsideratë sasinë e hyrjeve në një proçes të veçantë, sasinë e daljes në një proçes të veçantë dhe sasinë stok (një sasi që qëndron në sistem për një periudhë të caktuar dhe nuk duhen konsideruar si humbje apo mbetje). Çdo gabim në këtë kuptim, do të shkaktojë një balancë gabimesh të pa barabartë me zero, që do të thotë faza e planifikimit të aktiviteteve minerare do bëhet më e vështirë.

Kështu, hapi i parë trajton identifikimin e proçeseve dhe fluksin e sistemit që analizohet. Lidhja ndërmjet inputit dhe ouputit përfaqëson hapin e vleftësimit të të dhënave pasi nëse balanca nuk është nul, është mënjëherë evidente nëse ka mungesë të dhënash apo pasaktësi të tyre.

$$
\sum(\text { hyrje })=\Sigma(\text { dalje })+\sum \text { (Stok) }
$$




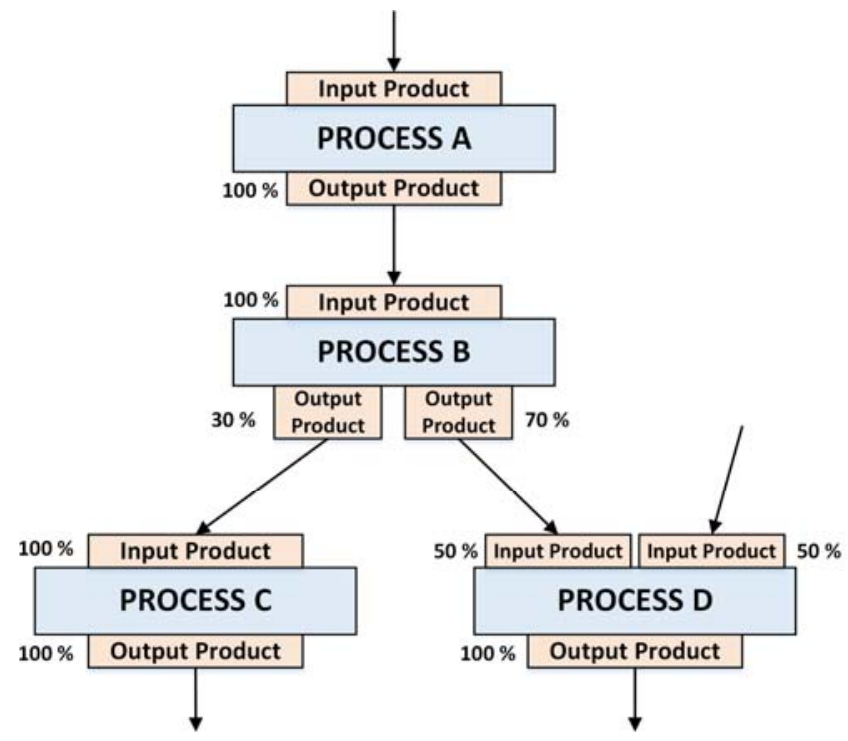

Figura 5.1: Shembull i lidhjes mes njësive të ndryshme të proÇesit përmes fluksit të materialeve

Me një proçes të tillë, është e mundshme të vendoset lidhja mes një ose më shumë grupeve fokusimi. Kjo mund të ndihmojë të krijohet një vizion më i gjërë i agregateve (nga dera në derë). Për më tepër, në këtë mënyrë është e mundur të identifikohen boshllëqet kryesore në sistemin e njësive, dhe rrjedhimisht, proçesin e mbledhjes së të dhënave. Në lidhje me gabimin në të dhëna, është e mundur të kryhet një ndërhyrje për fushatat e ardhshme të mbledhjes dhe ato të menaxhimit të të dhënave me qëllim përmirësimin. Disa shembuj specifik mund të gjinden në rastin studimor të Trento's (Blengini et al., 2014).

Integrimi i këtyre dy proçedurave vleftësimi mund të mbështesi identifikimin e boshllëqeve në strukturën e informacionit, dhe rrjedhimisht të vendosen disa prioritete lidhur me rinovimin e të dhënave, veçanërisht nëse është e mundshme të nënvizohen boshllëqe në informacion dhe apo divergjenca ndërmjet të njëjtave tipe të dhënash që janë mbledhur nga burime të ndryshme. Në varësi të përdorimit final të informacionit dhe të nivelit të planifikimit, është e mundshme të drejtohen përpjekjet drejt një korigjimi më të detajuar të të dhënave, psh rritjen e mbledhjes së të dhënave dhe të bashkëpunimit ndërmjet grupeve të interesit. 


\subsection{Analiza e fluksit të materialeve}

Fluksi i materileve përdor parimin e balancimit që u shpjegua në kapitullin më lart, dhe studion si fluksin e materialeve dhe energjive përmes ekonomisë dhe ambjentit nga dhe brenda vendeve. Parimi bazohet në ligjin e parë të termodinamikës i cili thekson se çështja (masa, energjia) as nuk krijohet dhe as nuk shkatërrohet nga një proçes fizik. Qëllimi i kësaj analize është të rrisi ndjekjen e fluksit të energjive dhe materialeve në ekonomi dhe mjedis, si dhe të rrisi dijet mbi përdorimin sa më efikas dhe ekonomik të materialeve. Gjithëashtu ndjek lëvizjen e çështjes brenda dhe jashtë sistemit të interesit, në rastin e sektorit agregat duke përdorur në mënyrë të organizuar materialin që disponohet, dhe duke e kaluar pjesën tjetër në stok.

Analiza e fluksit të materialeve është vlerësimi sistematik i fluksit dhe stokut të materilaeve brenda sistemit të interesit brenda një periudhë dhe kohe të caktuar. Ajo i përdor të dhënat e mësipërme për të trajtuar probleme specifike si psh kontrollimin e mënyres së përdorimit të materialit dhe proçeset industrial, promovimin e dematerializimit të rezultateve industrial, ose përcaktimin se sa agregate që nevoiten për të mbështetur ekonominë mund të garantohen nga burimet e brendshme. Këto rezultate mund të kontribuojnë në politikën e analizimit dhe planifikimit.

\subsection{Parashikimi i kërkesës}

Kërkesa për agregate derivon nga kërkesa për produkte dhe shërbime në ekonomi, si psh strehimi dhe transporti. Shtysat e rritjes së kërkesës janë rritja e popullsisë, rritja e standarteve të jetesës, dhe rritja ekonomike. Shtysat e uljes së kërkesës janë kostot e larta që sjellin çmime të larta, rritja e efiçensës, ngadalsimi ekonomik, ulja e intensitetit të përdorimit (ton për njësi të GDP), që është tipike në ekonomitë e pjekura dhe të zhvilluara. Një shkak tjetër i mundshëm i uljes së kërkesës për agregate primare është zëvëndësimi me materiale të ricikluara.

Parashikimi i kërkesës mund të bazohet në gjykimin expert ose në modele sasiore. Çdo model do të ketë nivelin e vet të kompleksitetit dhe detajeve, teorinë dhe metodën e implementimit. Ato që bazohen në karakteristikat sektoriale quhen modele nga poshtë lart. Ato që bazohen në intensitetin e përdorimit quhen modele nga lart poshtë. Modelet sektoriale zakonisht përfaqësojnë një lidhje hipotetike rastësore, ose një trend observimesh të mbledhura gjatë kohës. Të parat modelohen me një ose një set ekuacionesh ekonometrike që prezumojnë se kërkesa varet në një ose më shumë variabla p.sh aktiviteti ekonomik ose popullata. Ky i dyti prezumon se modeli i kërkesës së shkuar do të vijojë edhe në të ardhmen. 


\subsubsection{Parashikimi rastësor i kërkesës bazuar në planifikimin e përdorimit lokal të tokës}

Kjo përllogaritje mund të përftohet indirekt në vlera të përllogaritura, duke mbajtur në konsideratë punët infrastrukturore të shkuara dhe të planifikuara për të ardhmen (vepra ndërtimi publike apo private). Mirëmbajtja e tyre, rinovimi dhe restaurimi i tyre duhet të mbahet gjithashtu në konsideratë. Volumi i kërkesës agregate (Vest) është modeluar si një funksion i indeksit hapsinor dhe zonal. Të gjitha statistikat janë të raportuara në ton, prandaj përdorimi i kësaj metode do të lindte nevojën për konvertimin e tonëve në volume.

Vest $=($ Sha - Ped $) *$ It

ku Sha është sipërfaqja e zonave homogjene në $\left[\mathrm{m}^{2}\right]$, Ped është sipërfaqja e zonave të ndërtuara në $\left[\mathrm{m}^{2}\right]$, dhe It është indeksi hapsionr në $\left[\mathrm{m}^{3} / \mathrm{m}^{2}\right]$.

Volumi i përfituar në lidhje me zonat e ndërtimit shumëzohet me koficentin korespondues të përdorimit, p.sh sasia e agregateve për njësi volum. Për pasojë, mund të llogaritet sasia e materialeve të nevojshme për ekzekutimin e planeve të punës, dhe mirëmbajtjen e ndërtesave aktuale.

Kjo metodologji mund të jetë e vështirë për tu aplikuar, pasi bazohet në vlerësimin e nevojave të planifikimit lokal urban, dhe në veçanti në llogaritjet e planeve strategjik lokal, që specifikojnë ndërtimet e reja që priten të kryhen në vitet e ardhshme. Megjithëatë, vlerësimin bazuar në planet lokale të punës zakonisht parashikon një përllogaritje të fryrë, meqë bazohet në prezumimin se plani strategjik lokal do të implementohet plotësisht, çka jo zakonisht ndodh për shkak të faktorëve të ndryshëm.

Për më tepër, kjo metodologji përafron proporcionin e volumeve të ndërtimi që do mirëmbahen, rinovohen dhe restaurohen. Në përfundim, një kufizim i kësaj metodologjie është se neglizhon konsumimin e lidhur me disa vepra publike si psh rrugët, punët e industrive dhe morfologjia e territorit që mund të ndryshojë (ndoshta në mënyrë domethënëse) kërkesat për materiale.

\subsubsection{Parashikimi rastësor i kërkesë bazuar në popullatën ose aktivitetin ekonomik}

Qasja e parë, prezumon se kërkesa për agregate është një funksion i popullatës. Volumi aktual i konsumit të agregateve për frymë $\left(\mathrm{m}^{3} /\right.$ person) mund të përllogaritet si prodhimi total pjestim për popullatën. Projektimi i rritjes së popullatës kryhet 
përmes statistikave kombëtare, megjithëatë duhet të konsiderohet si një përafrim sepse i referohet mesatares kombëtare. Nëse popullata pritet të mbetet e pa-rritur, atëhere kërkesa do të mbetet konstante gjithashtu. Nëse popullata pritet të rritet, atëhere kërkesa do të rritet në mënyrë proporcionale. Kjo metodë prezumon se niveli i konsumimit do të vijojë të rritet si në të kaluarën. Në përgjithsi, kjo metodë nuk merr në konsideratë tregun ose trendet e kërkesës, dhe për pasojë mund të nën ose mbi vlerësojë kërkesën e ardhshme (Cabini \& Zobolu, 2011). Duhet theksuar gjithashtu, se meqënëse të gjitha statistikat e raportuara në ton, që përdorin këtë metodë, duhet ti konvertojnë tonët në volume.

Një metodë e ngjashme regresi bazohet në prezumimin se kërkesa është funksion i madhësisë së ekonomisë; nëse ekonomia po rritet, kërkesa për agregate do rritet dhe e kundërta. Historikisht, prodhimi i brëndshëm bruto ka qënë një parashikues i mirë i kërkesës agregate, por jo gjithmonë. Së pari, është efektive për aq kohë sa intensiteti i përdorimit rritet pasi ka një prezumim se me rritjen e ekonomisë rritet dhe kërkesa. Megjithëatë, njëherë që intensiteti i përdorimit bie, rritja ekonomike do të çojë në më pak konsumim. Së dyti, lidhja nuk merr në konsideratë përdorimin e zëvëndësuesve, si psh mbetjet e ricikluara nga Ndërtimi ose Shkatërrimi (C\&DW).

Gjithëashtu është e mundur, pavarësisht se më pak e zakontë, të ndërtohen modele më të komplikuara të lidhjes mes aktivitetit ekonomik dhe kërkesës. Një model ekonometrik i ekonomisë mund të krijohet bazuar në një set ekuacionesh lineare dhe jo lineare, të cilat ndërtojnë modelet më të komplikuara të lidhjes mes aktivitetit ekonomik dhe kërkesës. Një model ekonometrik i ekonomisë mund të krijohet bazuar në një set ekuacionesh lineare dhe jo lineare, të cilat zgjidhen njëkohësisht, si psh modelet e ekulibrit. Ose, një parashikim i kërkesës mund të gjenerohet nga përdorimi simulimeve të sistemit dinamik të modelimit. Parametri thelbësor ka të bëjë me ndërlidhjen e stoqeve dhe flukseve në ekonomi, të cilët janë pragu $i$ vlerësimit të GDP's dhe popullatës, paçka se lidhje të tjera mund të përfshihen gjithashtu.

\subsubsection{Parashikimi në kohë bazuar në statistikat e prodhimit}

Të dhënat "Zyrtare" statistikore lidhur me prodhimin e agregateve përdoren shumë shpesh për të planifikuar. Përdorimi i këtyre të dhënave, nësë e mundshme, si një parashikim për kërkesën, prezumon se prodhimi lokal shkon vetëm për nevojat lokale. Kjo çon në parashikim të gabuar për shumë arsye:

- Në zonat ku import-eksporti është i lartë, niveli i prodhimit vendas nuk reflekton kërkesën; 
- Statistikat e prodhimit, që sigurohen nga autoritetet lokale, nuk kanë një shkallë të lartë besueshmërie dhe herë pas here nuk mbajnë në konsideratë tipet e ndryshme të materialeve; dhe

- Në të tilla raste, tipi i materialeve të nevojshme nuk mund të përllogaritet saktë, dhe për pasojë skema e MQBA nuk mund të zhvillohet.

Duke prezumuar se statistikat e prodhimit janë të vlefshme, një trend i përgjithshëm për prodhimin e agregateve mund të përllogaritet pasi të dhënat vjetore janë filtruar dhe të jenë hequr gabimet. Metoda eksponenciale mund të perdoren për të përgatitur të dhënat lineare ose jo lineare. Një analizë e tillë mund të japi indikacionet e prodhimit mesatar për vitet e ardhshme. Karakteristikat kryesore të sistemit të plotë të prodhimit prezumohet se reflektohen në të dhëna, megjithëatë influence e faktorëve rastësor nuk konsiderohen direkt. Këto përfshijnë faktorë që afektojnë prodhimin, si psh taksimi apo ekonomija lokale.

Është tepër e rëndësishme që trendi $i$ të dhënave të përditësohet rregullisht duke monitoruar rregullisht aktivitetet dhe duke krahasuar rezultatet e parashikimeve të shkuara. Kjo është veçanërisht e rëndësishme meqënëse disa të dhëna mund ti përkasin një periudhe krize e cila mund të mos parashikojë saktë rritjen e kërkesës gjatë rritjes ekonomike. Kjo qasje mund të jetë e dobishme thjesht për efekt krahasimi por nuk është e saktë për përllogaritjen e kërkesës agregate ne të ardhmen (Cabini \& Zoboli, 2011; Mazzanti et al., 2007; Keshilli Komunal Worchestershire, 2013).

\subsubsection{Parashikimi në kohë bazuar në statistikat e konsumit}

Edhe këtu qasja e parashikimit është metodologjikisht e ngjashme me seksionin më lart. Bazohet në vlerat e konsumit agregat për një rajon të caktuar në një kohë të caktuar bazuar në parimin e vijimësisë, p.sh konsumi $i$ ardhshëm mund të përllogaritet nga të dhënat aktuale dhe të shkuara të konsumit. Rezultatet mund të rishikohen dhe përditësohen duke vlerësuar projektet e ndërtimit në raport me të kaluarën, psh punët e planifikuara që janë financuar.

Përdorimi i të dhënave historike të konsumit (zakonisht 5 ose 10 vite) për këtë analizë, mund të parashikojë në terma afatmesëm një parashikim kërkesë. Vështirësia në këtë rast bazohet te vlefshmëria dhe saktësia statistike e informacionit. Si një shembull, në shumicën e rasteve, statistikat e konsumit agregat për përdorimin e fundit nuk janë të vlefshme, dhe rrjedhimisht palnifikimi duke përdorur MQBA bëhet i pamundur. Kur disa të dhëna nuk janë të vlefshme, disa përllogaritje mund të përfitohen indirekt përmes përdorimit të të dhënave të 
konsumit të materialeve të tjera që përdoren së bashku me agregatet, apo ndoshta statistika të kostove të prodhimit për punët publike të mbaruara. Shpesh konsumi agregat mund të vlerësohet përmes përdorimit të koeficientëve.

Volumi bruto i përdorur në veprat civile mund të ndahet në dy kategori (a) agregatet e përdorura për ndërtimin e veprave publike (infrastrukturore) dhe (b) agregate të përdorura si material nën bazë. Në rastin e ndërtesave, përllogaritjet e konsumit mund të zhvillohen duke vlerësuar indirekt sasitë relative, p.sh bazuar në volumet e raportuara në liçensat për ndërtim, nëse është e mundshme. Në rastin e ndërtesave, konsumi agregat është i lidhur me volumin e ndërtimeve, sipërfaqeve, dhe numrit të kateve etj.

Veprat publike i shërbejnë kryesisht zonave residenciale, dhe, rrjedhimisht, mund të prezumohet që janë proporcionale me volumet e ndërtesave. Shpesh herë, është e mundur të përllogaritet raporti ndërmjet materialeve të përdorura në vepra publike dhe në ndërtesa. Duke qënë se në shumicën e rasteve, të dhënat direkte lidhur me konsumin agregat në veprat publike janë të vlefshme, shpenzimet mund të përdoren si parametër reference. Këto shpenzime mund te lidhen me ndërtimin, mirëmbajtjen, rinovimin dhe restaurimin. Në përgjithësi, veçohen dy tipe veprash publike: a) ndërtesa civile dhe industrial, dhe b) rrugë, autostrada, hekurudha, ura, metro, aeroporte dhe punë të tjera komplementare me to.

Gjithëashtu, duke krahasuar të dhënat historike mbi ndërtesat dhe veprat publike në lidhje me volumin total të agregateve që është prodhuar nga minierat dhe burimet alternative, është e mundur të përcaktohen koeficientët e përdorimit që lidhen me rastin specifik si dhe periudhën në shqyrtim. Qartazi, këto koeficientë janë të lidhura me tipet e ndërtesave të marra në konsideratë, dhe bazohen në përdorimin e agregateve për ndërtimin e këtyre ndërtesave (themele, struktura mbajtëse, etj). Një set tjetër koefiçientësh duhet të përdoret për të vlerësuar sasinë e agregateve përdorur për punë që lidhen me strukturat kryesore të ndërtesës.

Një variacion i kësaj qasje përdoret në Mbretërinë e Bashkuar, ku konsumi agregat parashikikohet bazuar në trendet intensive të përdorimit alternative të agregateve (shtëpi, infrastruktura), trendet më pak intensive të përdorimit të agregateve (riparimi i shtëpive, industrial) dhe përdorimi intensive. Këto të dhëna janë përcatuar si të përshtatshme dhe të nevojshme. Parashikimi prezumon se lidhjet historike do të vijojnë në të ardhmen, prandaj është thelbësore të përditësohen parashikimet të paktën çdo 6 muaj në mënyrë që të kapen ndryshimet (UK Gov, 2014). 
54 


\section{Rekomandime}

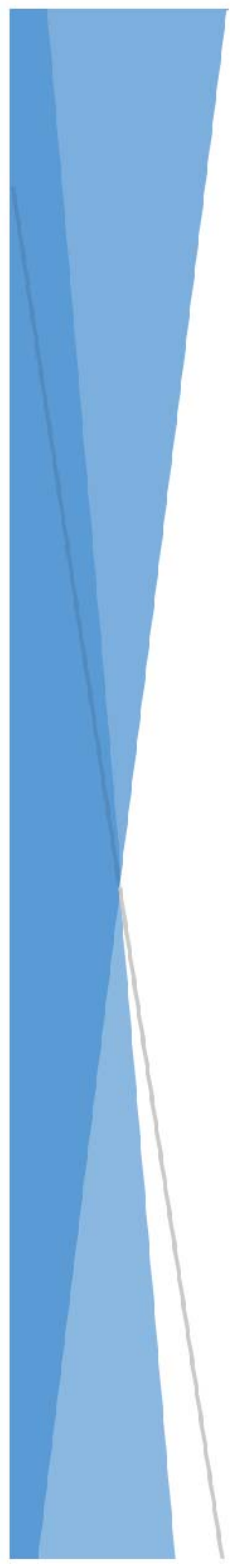

Në këtë seksion jepen Rekomandime te Përgjithëshme. Sejcili prej vendeve dhe rajoneve duhet të adoptojnë këto rekomandime në mënyrë që të përshtasin proçesin $e$ planifikimit. 


\subsection{Rekomandime të përgjithshme}

Më poshtë jepen një numër rekomandimesh lidhur me të dhënat dhe analizimin e të dhënave që nevoitet për planifikimin e qëndrueshëm të agregateve.

- Këkresa për agregate në vendet e EJL duhet të trajtohet me një një miks të agregateve primare dhe sekondare (p.sh mbetje e ricikluar ndërtimi apo shkatërrimi ndërtesash, agregate të fabrikuara, materiale të nxjerra nga vepra publike, etj) sipas parimeve të efikasitetit të burimeve. Në fakt, burime të shumfishta furnizimi mund të kontribuojnë për të kënaqur ofertën.

- $\quad$ Autoritetet planifikuese duhet të identifikojnë burimet e vlefshme minerale që përmbushin kërkesat e cilësisë, aksesueshmërisë dhe kërkesat teknike për burimet agregate në zonat e tyre, gjatë përgatitjes së planeve.

- Është e rëndësishme për vendet/rajonet e EJL të adoptojnë dhe impelementojnë një politikë planifikimi të përdorimit të tokës për agregatet në mënyrë që të promovojnë investimet në industrin e nxjerrjes minerare.

- $\quad$ Një politikë e qëndrueshme për agregatet duhet të ruajë zhvillimin agregat dhe planifikimin e përdorimit të tokës për operacoinet e ardhëshme minerare në këto zona. Hartat e përdorimit të tokës duhet të jenë të vlefshme në nivelin lokal, rajonal dhe kombëtar.

- Të gjithë aktorët e interesuar, p.sh ato që janë përgjegjës për proçesin e planifikimit të agregateve primare dhe sekondare dhe përdorimin $e$ qëndrueshëm të burimeve natyrore, sikundër dhe industria, komunitetet lokale, OJF dhe shoqëria civile duhet të punojnë në bashkëpunim të ngushtë.

- $\quad$ Planifikimi i agregateve duhet të rishikohet në intervale kohore, në mënyrë që të sigurojë se është i përditësuar me kërkesat aktuale, kornizën ligjore dhe detyrime të tjera.

- Vendet/rajonet e EJL duhet të konsiderojnë shkëmbimin e të dhënave mbi agregatet në mënyrë që të shqyrtojnë mundësitë e import-eksportit ndërmjet vendeve fqinje. 


\subsection{Rekomandime mbi të Dhënat dhe Metodologjonë e Analizimit të të Dhënave}

Më poshtë paraqiten rekomandime specifike lidhur me si të përmirsohet mbledhja e të dhënave, vleftësimi dhe analizimi i tyre:

- Duhet të vendosen proçedura efikase për mbledhjen e të dhënave, menaxhimin dhe përpunimin e tyre në mënyrë që të zhvillohen politikat e Menaxhimit të Qëndrueshëm të Burimeve Agregate MQBA dhe FQM Furnizimi i Qndrueshëm Miks.

- Vendimarrja duhet të bazohet në të dhënat më të mira që janë në dispozion, si dhe në ato që janë shkencërisht të provuara nga burime të njohura. Të dhënat duhet të kontrollohen imtësisht dhe të vleftësohen përpara përpunimit.

- Anketime të rregullta duhet të kryhen mbi informacion të përditësuar mbi rezervat, burimet, konsumin dhe volumet e prodhimit, flukset inter rajonale, transportin, rezervat e lejuara të agregateve primare, në shkallë kombëtare dhe apo rajonale, në varësi të nivelit të planifikimit.

- Duhet të ndërtohet një matricë informacioni për çdo nivel planifikimi që të identifikojë proçeset dhe të dhënat që nevoiten për çdo proçes.

- Parashikimi i kërkesës duhet të kryhet duke përdorur metodologjinë më të përshtatshme në çdo rajon/vend. Informacioni duhet të përmbajë vepra publike dhe private, exportet etj.

- Të gjitha të dhënat duhet të organizohen në një bazë të dhënash elektronike e cila duhet përditësuar rregullisht. Si shembull, një direktori me miniera agregate (të lejuara) aktive ose inaktive së bashku me të dhënat për kapacitetin prodhues.

- Të dhënat duhet të vleftësohen në mënyrë te tille që të sigurohet besueshmëria e informacionit. 


\section{Referenca}

Agioutantis Z., Komnitsas, K.\& Athousaki, A. (2013). Transporti Agregat dhe Përdorimi në Zonat Urbane: Impakti Ekologjik dhe Mjedisor, Punimet e Konferencës së 13 Kombëtare, Chania, Greqi, 5-8 Shtator 2013, Buletini i Shërbimit Gjeologjik Grek, vol. XLVII 2013.

Austria, (2014). http:// www.en.bmwfw.gv.at/Energy/Seiten/TheAustrianMineralResourcesPlan.aspx

BGS (2014a). http:// www.bgs.ac.uk/planning4minerals/Glossary.htm

BGS (2014b). http:// www.bgs.ac.uk/planning4minerals/Resources_4.htm

BGS (2014c). http:// www.bgs.ac.uk/planning4minerals/Resources_5.htm

BGS, (2012). "Harta e ruajtjes së Agregateve Uells", Keyworth, Nottingham, Shërbimi Gjeologjik Britani.

Blengini, G.A., Moltrer, A., Valbusa, M., Komnitsas, K., Agioutantis, Z. \& Garbarino, E. (2013). Të dhëna dhe metodologjia për planifikimin efikas te burimeve agregate primare dhe sekondare në Europën Jug Lindore EJL, Punimet e Konferencës së 6 Ndërkombëtare mbi Indikatorët e Zhvillimit të Qëndrueshëm ne Industrinë Minerare (SDIMI 2013), 30 Qershor - 3 korrik 2013, Milos, Greece, fq. 282-288.

Blengini G.A., Bobba S., Shields D.J., Moltrer A. \& Valbusa M. (2014). Raport mbi Metodologjinë e Analizimit të të Dhënave, projekti MQBA -EJL.

Cabini, E., \& Zoboli, R. (2011). Kërkim për dimensionimin e volumeve të përbërjeve minerare për Provincën e Kremonës. Shkolla e Lartë për Ambjentin- Universiteti Katolik i Breshias.

Chalkiopoulou, F. \& Hatzilazaridou, K. (2011). Si të arrihet efikasiteti i burimeve agregate në komunitetet lokale, një manual i përbashkët për grupet e interesit, SARMa Manual, http://www.sarmaproject.eu.

Hatzilazaridou, K. (2014). Data Dictionary, SNAP-SEE, http:// www.snapsee.eu.

Leoben (2010). Politikat e Planifikimit dhe Proçedurat e Lejuara për të Siguruar Furnizim të Qndrueshëm të Agregateve në Europë, Raporti Përfundimtar, i komisionuar nga UEPG, Departamenti i Burimeve Natyrore dhe Inxhinierisë Hidrokarbure, Univeriteti i Leoben, Austri, Qershor. 
Mazzanti, M., Paleari, S.\& Zoboli, R. (2007). Efikasiteti taksave mjedisore dhe detyrimeve mbi nxjerrjen e rërës, zhavorrit dhe gurëve, në vendet e zgjedhura të BE- Itali.

SA, (2014). http:// www.sustainableaggregates.com/sourcesof aggregates/recycle/

SARMa (2011). http:// www.sarmaproject Revista vjetore 2012-2013.

http://ëëë.uepg.eu/uploads/Modules/Publications/uepg-ar2012-

2013_en_inter_v14_pbp_small.pdf

UK Gov (2014). https://

www.gov.uk/government/uploads/system/uploads/attachment_da-

ta/file/6286/forecastingaggregatesdemand.pdf.eu/

SEA, (2001). Direktiva 2001/42/EC “Mbi vlerësimin e efekteve e planeve dhe programeve të caktuara në mjedis"

SPP, (2006). Politika planifikuese Skoceze SPP4 "Planifikimi i Minerale", www.scotland.gov.uk/publications/2006/08/30152427].

Springer (2014). http://

www.springerreference.com/docs/html/chapterdbid/349568.html.

UEPG

Asambleja qeveritare e Uellsit, Departamenti i Komuniteteve dhe Qeverisjes Lokale (2011) "Kualicioni i rezultateve të anketimit për agregatet minerale të Anglisë dhe Uellsit 2009", Botimi i Dytë, Tetor 2011.

Këshilli i Kontesë Worchestershire, (2013). Plani Lokal për. Vlerësimi lokal i agregateve Worcestershire, http:// www.worcestershire.gov.uk / mineralsbackground

http://www.aggregate.com/glossary-of-terms/\#sthash.oqjYPj46.dpuf

http:// www .businessdictionary.com/definition/demand-forecast.html

http://economics.about.com/cs/economicsglossary/g/demand.htm

http:// www.oecd.org/environment/indicators-modelling-outlooks/MFA-Guide.pdf

http:// www.scotland.gov.uk/publications/2010/02/03132605/12

http:// www.scotland.gov.uk/publications/2006/08/30152427/0 




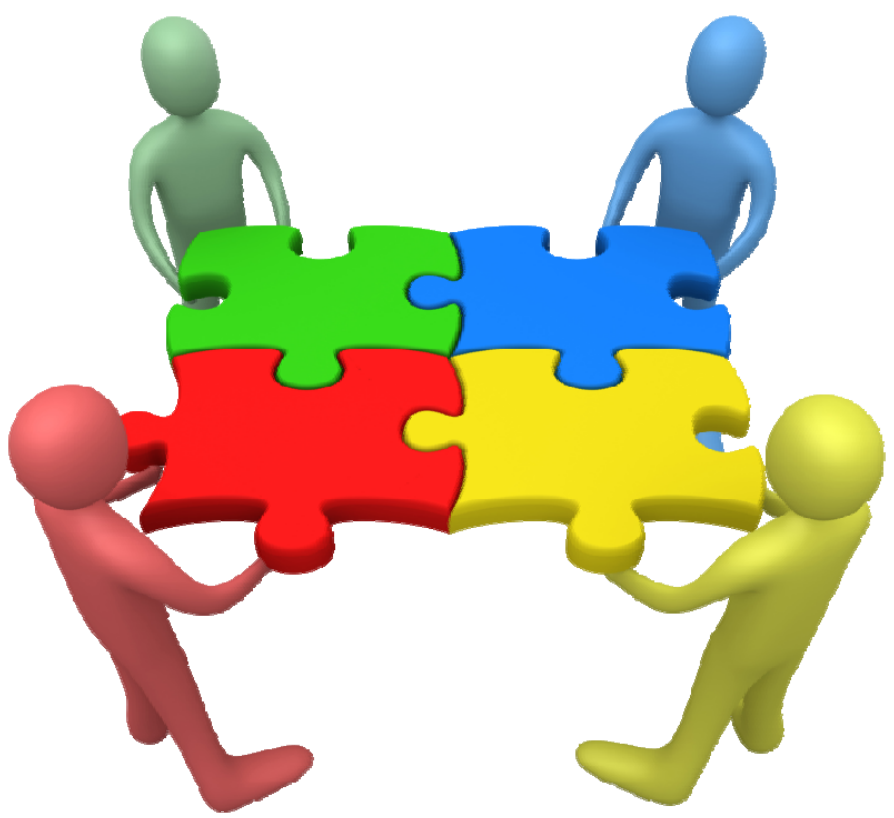

Planifikimi i Qëndrueshëm i Agregateve në Europën Juglindore (SNAP-SEE) 